\title{
Diversity of bacterial strains in biochar-enhanced Amazon soil and their potential for growth promotion and biological disease control in tomato
}

\author{
Matheus Miranda CANIATO ${ }^{1,2}$, Aricléia de Moraes CATARINO ${ }^{1, *}$ (i) Thiago Fernandes SOUSA ${ }^{3}$, Gilvan \\ Ferreira da SILVA ${ }^{3}$, Karina Pryscilla de Araújo BICHARA ${ }^{1,3}$, Jeferson Chagas da CRUZ ${ }^{3}$, Luiz Alberto \\ Guimarães de ASSIS $^{1}$, Rogério Eiji HANADA ${ }^{4}$ \\ Instituto Nacional de Pesquisas da Amazônia, INPA, Programa de Pós Graduação em Agricultura no Trópico Úmido, Manaus, Amazonas, Brazil \\ Instituto Federal de Educação, Ciência e Tecnologia do Amazonas, IFAM, Manaus, Amazonas, Brazil \\ Embrapa Amazônia Ocidental, Manaus, Amazonas, Brazil \\ ${ }^{4}$ Instituto Nacional de Pesquisas da Amazônia, INPA, Coordenação de Tecnologia e Inovação - COTEl, Manaus, Amazonas, Brazil \\ * Corresponding author: amoraescatarino@gmail.com; (DD https://orcid.org/0000-0002-5579-8625
}

\begin{abstract}
The use of bacteria in growth promotion and biological control of plant diseases can minimize environmental contamination caused by the indiscriminate use of pesticides and chemical fertilizers. We aimed to evaluate growth promotion and biological control of Corynespora cassiicola in tomato seedlings mediated by beneficial bacteria isolated from a non-rhizospheric Amazon soil containing different amounts of biochar, and to identify to which groups of bacteria the strains belong. We obtained 200 strains of bacteria from experimental plots containing biochar doses of $0,40,80$ and $120 \mathrm{t} \mathrm{ha}^{-1}$. Of these, 53 strains were selected by root colonization tests. Based on growth promotion parameters, 25 strains were screened, identified by molecular characterization and evaluated for indoleacetic acid (IAA) production, phosphate solubilization and biological control. The best dose of biochar for colony formation was $40 \mathrm{t} \mathrm{ha}^{-1}$, and a regression model indicated $34 \mathrm{t} \mathrm{ha}^{-1}$ as the optimal dose. The production of IAA was observed in $18(75 \%)$ strains, and two (8\%) strains were able to solubilize phosphate. The efficiency in root growth promotion was up to $125 \%$, and the percentage of plant protection ranged from 50 to $59 \%$. Molecular characterization showed that the bacteria used in this study belong to the genera Bacillus and Lysinibacillus.
\end{abstract}

KEYWORDS: beneficial bacteria; Corynespora cassiicola; Solanum lycopersicum; target spot

\section{Diversidade de isolados bacterianos em solo amazônico enriquecido com biocarvão e seu potencial para a promoção de crescimento e controle biológico de doenças em tomate}

\section{RESUMO}

O uso de bactérias na promoção do crescimento e no controle biológico de doenças em plantas pode minimizar a contaminação ambiental causada pela aplicação indiscriminada de pesticidas e fertilizantes químicos. Objetivamos avaliar a promoção do crescimento e o controle biológico de Corynespora cassiicola em mudas de tomate mediadas por bactérias benéficas isoladas de solo amazônico não-rizosférico contendo diferentes dosagens de biocarvão, e identificar a quais grupos de bactérias os isolados pertencem. Obtivemos 200 isolados de parcelas experimentais contendo doses de biocarvão de 0, 40, 80 e $120 \mathrm{t} \mathrm{ha}^{-1}$. Destes, 53 foram selecionados por testes de colonização radicular. Com base nos parâmetros de promoção do crescimento, 25 isolados foram selecionados, identificados através de análise molecular e avaliados para produçáo de ácido indolacético (AIA), solubilização de fosfato e controle biológico. A melhor dose de biocarvão para a formação de colônias foi $40 \mathrm{t}$ ha ${ }^{-1}$, $\mathrm{e}$ um modelo de regressão indicou $34 \mathrm{t} \mathrm{ha}^{-1}$ como dose ótima. A produção de AIA foi observada em 18 (75\%) isolados e dois (8\%) isolados foram capazes de solubilizar fosfato. A eficiência na promoção do crescimento das raízes foi de até $125 \%$, e a porcentagem de proteçẫo das plantas variou de 50,3 a 59,0\%. A caracterizaçáo molecular indicou que as bactérias utilizadas nesse estudo pertencem aos gêneros Bacillus e Lysinibacillus.

PALAVRAS-CHAVE: bactérias benéficas; Corynespora cassiicola; Solanum lycopersicum; mancha alvo 


\section{INTRODUCTION}

Tomato (Solanum lycopersicon Linnaeus) is one of the most commonly produced vegetables worldwide (Faostat 2017). In Amazonas state, Brazil, tomato cultivation is hampered by soil acidity and low natural fertility (Cerri et al. 2003) and requires high doses of limestone and chemical fertilizers, which significantly increase the costs of tomato production and discourage farmers. In addition, diseases caused by fungi are a limiting factor in tomato crops. Target spot, caused by the fungus Corynespora cassiicola (Berk and M. A. Curtis) C.T. Wei. is among the most important diseases that affect the aerial parts of tomato seedlings (Mandal et al. 2017). Corynespora cassiicola is non-specific and occurs mainly in the tropics and subtropics (Dixon et al. 2009), where environmental conditions favour disease development (Teramoto et al. 2017). In Brazil, there are still no specific fungicides recommended by the Ministry of Agriculture for the control of target spot in tomato crops. Therefore, the disease is controlled by fungicides recommended for soybean crops, such as Carbendazim Nortox and Comet', which have benzimidazole and strobirulin, respectively, as active ingredients (Agrofit 2020). These agents can cause harm to the environment, plants, animals and humans (Chaturvedi et al. 2013).

Beneficial bacteria in soils have potential to promote both biocontrol, because some produce natural fungicides to control phytopathogens, and plant growth, because some produce phytohormones (e.g., indoleacetic acid) and siderophores, and solubilize minerals, such as silicates, phosphates and potash (Naureen et al. 2017). Biochar applied to the soil can enhance colonization by beneficial bacteria, including plant growthpromoting bacteria (PGPB) (Bertola et al. 2019). Biochar can improve soil health with or without exposure to contamination by heavy metals and/or organic pollutants (Palansooriya et al. 2019). Biochar improves composting processes, as well as the biochemical properties of compost, by increasing the number of plant growth-promoting rhizobacteria (PGPR), which solubilize phosphate, produce indoleacetic acid (IAA) and degrade protein and cellulose. Biochar can also synergize the use of biofertilizers for promoting sustainable agriculture (Antonius et al. 2015).

Through increases in bacterial abundance and changes in microbial community structure, biochar soil-enrichment can exert a significant role on disease suppression and plant growth promotion, either through direct antagonism or indirectly via induction of systemic resistance in the plant (Jaiswal et al. 2018). Biochar amendments in soil can reduce the severity of bacterial wilt caused by Ralstonia solanacearum on tomato (Lu et al. 2016), induce resistance to the pathogens Botrytis cinerea and Leveillula taurica in both pepper and tomato, and the pest Polyphagotarsonemus latus in pepper (Elad et al. 2010), and improve considerably the growth of tomato plants, as they become more resistant to Fusarium oxysporum and Ralstonia solani (Khalifa and Thabet 2015).

Our aim was to evaluate growth promotion and biological control of $C$. cassiicola in tomato seedlings mediated by beneficial bacteria from a non-rhizospheric Amazonian soil containing different amounts of biochar, and to identify to which groups of bacteria the strains belong.

\section{MATERIAL AND METHODS}

\section{Influence of biochar on soil cultivable bacterial populations}

The non-rhizospheric soils used were obtained at the Experimental Station for Tropical Fruit Culture of Instituto Nacional de Pesquisas da Amazônia (INPA), located at km 42 of the BR-174 highway, municipality of Manaus, Amazonas state, Brazil. The soil in the area is dystrophic yellow Oxisol with clay texture (> 60\%). Soil samples were collected in 2017 from $25-\mathrm{m}^{2}$ plots that had been enriched with biochar (Table 1) at concentrations of $0,40,80$ and $120 \mathrm{t} \mathrm{ha}^{-1}$ in 2006 (one plot per treatment). A maize/cowpea crop rotation was started on the plots three months after biochar application, when a chemical fertilization ( $66 \mathrm{~kg} \mathrm{ha}^{-1}$ of urea, $177 \mathrm{~kg} \mathrm{ha}^{-1}$ of triple superphosphate and $100 \mathrm{~kg} \mathrm{ha}^{-1}$ of $\mathrm{KCl}$ ) was applied. Three samples were collected from each plot at depths between 0 and $10 \mathrm{~cm}$, and mixed into a composite sample. About $300 \mathrm{~g}$ of each sample was packed into plastic bags and transported in a polystyrene box to the Phytopathology Laboratory at INPA.

Bacterial strains were isolated by the serial dilution methodology (Silva and Romero 2004), with dilution factors varying from $10^{-1}$ to $10^{-4}$. After dilution, strains were cultivated using solid 523 non-selective culture medium (Kado and Heskett 1970). Colonies were obtained according to the methodology of Silva and Romero (2004), using $10^{-4}$ dilution factor aliquots of $100 \mu \mathrm{L}$, which were deposited in Petri dishes containing the culture medium and maintained at $28^{\circ} \mathrm{C}$ in biochemical oxygen demand (BOD) during 24-hours of light. The results were expressed in colony forming units per $\mathrm{ml}$ $\left(\mathrm{CFU} \mathrm{ml} \mathrm{m}^{-1}\right.$ ) using the formula: $\mathrm{R}=\mathrm{a} \times 10^{\mathrm{b}} \mathrm{CFU} \mathrm{m}{ }^{-1}$, where $\mathrm{R}=$ result, $\mathrm{a}=$ average number of colonies per repetition and $\mathrm{b}=$ exponent of the dilution.

The experiment was conducted in a completely randomized design with four biochar treatments $\left(0,40,80\right.$ and $\left.120 \mathrm{t} \mathrm{ha}^{-1}\right)$ and five replications. Each replication consisted of one Petri dish. Fifty colonies were selected for each treatment, totaling

Table 1. Concentrations of chemical elements in the biochar-enriched nonrhizospheric soil collected at the Experimental Station of Tropical Fruticulture - EEFT/INPA, municipality of Manaus (Amazonas, Brazil) in 2017.

\begin{tabular}{lccccccccc}
\hline Material & $\mathbf{C}$ & $\mathbf{N}$ & $\mathbf{C a}$ & $\mathbf{M g}$ & $\mathbf{K}$ & $\mathbf{P}$ & & $\mathbf{Z n}$ & $\mathbf{M n}$ \\
\cline { 2 - 5 } & \multicolumn{9}{c}{$\mathrm{g} \mathrm{kg}^{-1}$} \\
Fine coal & 873.3 & 8.9 & 6.2 & 1.3 & 2.1 & 0.2 & & 12.0 & 67.0 \\
\hline
\end{tabular}


200 strains. Colonies were selected by appearance, for uniform color and shape. Selected strains were isolated in solid medium (Kado and Heskett 1970) and the colonies were maintained at $28^{\circ} \mathrm{C}$ during $24 \mathrm{~h}$ of light in BOD.

\section{Root colonization of tomato seedlings}

After colony growth of the 200 selected strains, a bacterial suspension was obtained by adding $10 \mathrm{ml}$ of saline solution $(0.85 \%)$ to be used in the microbiolization step. The concentrations of the suspensions were adjusted by dilution, according to the correlation between optical density and number of CFU's, to 0.2 absorbance (Abs.) $(540 \mathrm{~nm})$, which corresponds to approximately $10^{8} \mathrm{CFU} \mathrm{ml}^{-1}$.

Untreated Santa Cruz Kada tomato seeds were disinfested by immersion in ethanol (50\%) for two minutes, $\mathrm{NaCl}$ $(2 \%)$ for four minutes and washing in sterilized water. The microbiolization was performed according to Silva et al. (2003). After this phase, seeds were sown in tubes containing 523 Kado and Heskett culture medium for 10 days. For each bacterial strain, three tubes containing two seeds each were used. In addition to the 200 strains, we used the rhizobacterium Bacillus cereus Frankland \& Frankland, 1887 (UFV-101 strain) as positive control, as it has proven efficiency in root colonization (Romeiro et al. 2010). The presence of a halo around the root was used as an indicator of colonization. Each isolate was categorized as positive or negative for root colonization capacity. A light microscope with a magnification of 100x was used to observe bacterial biofilm formation.

\section{Growth promotion of tomato seedlings}

This experiment was performed at the Von der Pahlen Experimental Station for Vegetable Crops of INPA, and was divided into two steps. First, a preliminary selection was carried out among the positive strains for root colonization. The second step consisted of the confirmation test with the most promising strains. For both steps, the bacterial strains were grown in Petri dishes containing medium 523 (Kado and Heskett 1970), for 24 to 48 h. Tomato seeds (cultivar Santa Cruz Kada) were immersed in the bacterial suspension of each selected strain for a period of $24 \mathrm{~h}$ by microbiolization, then were sown in tubes $(280 \mathrm{~g})$ containing Vivatto Plus substrate (two seeds per tube), with 10 tubes per treatment. Thinning was performed seven days after germination, leaving one seedling per tube. The experimental design was completely randomized. Two controls were used, one negative, with microbiolized seeds in sterilized distilled water, and one positive, with microbiolized seeds in B. cereus (UFV-101), with 10 replicates each.

In the first step, the effect of the bacterial strains on tomato seedling growth was evaluated through plant height $(\mathrm{PH})$, number of leaves (NL), stem diameter (SD) and dry mass of the aerial part (DMAP). In the second step, the most promising strains were reassessed through the same growth parameters (except NL), and also including the dry mass of the roots (DMR) and the total dry mass (TDM). PH was measured from the base to the apical bud of the seedling, using a millimetre ruler. NL was obtained by counting all fully expanded true leaves. SD was measured with a digital caliper (ZAAS). DMAP and DMR were obtained by weighing the aerial part and root dry mass, respectively. Samples were dried in a Digital Stove timer SSD 110L.

The growth promotion efficiency (GPE) was calculated for each variable and isolate selected in the second step using the data of both steps. GPE was calculated as $\left(\left[\mathrm{G}_{\mathrm{T}}-\mathrm{G}_{\mathrm{C}}\right] / \mathrm{G}_{\mathrm{C}}\right) \mathrm{x}$ 100 , where $G_{T}$ is the growth parameter for the isolate, and $G_{C}$ is the growth parameter for the negative control, as described by Almoneafy et al. (2014). All evaluations were performed 20 days after sowing.

\section{Indoleacetic acid production and phosphate solubilization}

The strains selected in the second step of the growth promotion assay and $B$. cereus strain (UFV-101) were grown in Petri dishes containing 523 solid medium (Kado and Heskett 1970). After $24 \mathrm{~h}$, they were transferred to test tubes containing $5 \mathrm{ml}$ of TS medium enhanced with hydroxytryptophan ( $3 \mathrm{~g}$ tryptone, $0.1 \mathrm{~g}$ soy peptone, $1.6 \mathrm{~g}$ $\mathrm{NaCl}, 0.2$ g hydroxytryptophan, and $200 \mathrm{ml}$ sterilized distilled water), and amino acid similar to L-tryptophan produced in capsules containing $50 \mathrm{mg}$ of 5-HTP. After $24 \mathrm{~h}$ under 130 rpm stirring, the medium was transferred to $10 \mathrm{ml}$ Falcontype tubes.

The production of indoleacetic acid (IAA) was determined by the colorimetric method, following Bric et al. (1991), using the Salkowski reagent $\left(0.5 \mathrm{M} \mathrm{FeCl}_{3} .6 \mathrm{H}_{2} \mathrm{O}\right.$ and $\left.35 \% \mathrm{HClO}_{4}\right)$, and three replicates per strain. The tubes were centrifuged and $2 \mathrm{ml}$ of the supernatant were placed in assay tubes with $1 \mathrm{ml}$ $(2: 1)$ of the reagent. The strains were incubated in the absence of light for $20 \mathrm{~min}$ for the reaction to occur. A reddish color in the tube signaled the production of IAA by the bacteria.

The evaluation of solubilization was based on Katznelson and Bose (1959). Strains were cultivated and maintained at 28 ${ }^{\circ} \mathrm{C}$ for 15 days, with three replicates per strain. The colonies that formed a clear halo around them were considered calcium phosphate solubilizers. The diameters of the colonies and solubilization halos were measured to obtain the solubilization index (SI), using the formula: SI = Ø Halo (mm) $\varnothing$ Colony $(\mathrm{mm})$ (Berraquero et al.1976), where $\varnothing=$ diameter. The bacteria were classified as low $(\mathrm{SI}<2)$, medium $(2 \leq \mathrm{SI}<4)$ and high solubilizers $(\mathrm{SI}>4)$. According to the starting time of solubilization, the bacteria were classified as precocious (solubilization onset before the third day) or late solubilizers (onset after the third day), and apparent non-solubilizers (that did not show visible solubilization until the 15 th day of evaluation) (Hara and Oliveira 2004). 


\section{Biological control}

This experiment was conducted in a greenhouse at EEH, aiming to control target spot caused by the pathogen $C$. cassiicola using the strains selected in the second step of the growth promotion assay. The INPA 2839 C. cassiicola strain was cultivated in potato-dextrose-agar medium (PDA). On the tenth day of growth, which coincided with the twentieth day of Santa Cruz Kada cultivar tomato seedling growth, the spore suspension was prepared with $1.1 \times 10^{5}$ spores $\mathrm{ml}^{-1}$ and applied to the seedlings using an atomizer. Subsequently, seedlings were placed in a humid chamber for $24 \mathrm{~h}$. The biocontrol agents (bacterial strains) were added 20 days before the pathogen following the protocol used in the growth promotion trials. The experimental design was completely randomized, with 10 replicates for each bacterial strain and three controls, which consisted of (i) plant $+B$. cereus UFV$101+$ C. cassiicola (positive control); (ii) plant + C. cassiicola (negative control); and (iii) plant + water (negative control).

The severity of the disease induced by $C$. cassiicola was evaluated on alternate days starting on the second day after inoculation with the pathogen and ending on the tenth day. Three leaflets per replicate were evaluated with the aid of an adapted Horsfall-Barratt diagrammatic scale (Oliveira et al. 2006) and classified according to the proportion of injured area as follows: 0 - no symptoms; $1-<1 \%$ injured area; 2 1.1 to $3 \%$; $3-3.1$ to $6 \%$; $4-6.1$ to $12 \%$; $5-12.1$ to $25 \%$; $6-25.1$ to $50 \%$; and 7 - > 50\%.

The area under the disease progression curve (AUDPC) $=\Sigma\left(\left(\mathrm{Y}_{\mathrm{i}}+\mathrm{Y}_{\mathrm{i}+1}\right) / 2\right)\left(\mathrm{t}_{\mathrm{i}+1}-\mathrm{t}_{\mathrm{i}}\right)$ was calculated for each strain and control from the data obtained for severity, where $Y=$ intensity of the disease, $t=$ time, and $\mathrm{i}=$ number of evaluations in time (Campbell and Greaves 1990). The protection percentage (\%) was estimated by the relationship: $(1-x / y)$, where $x=$ AUDPC of the treated plants, and $\mathrm{y}=\mathrm{AUDPC}$ of the inoculated controls (Li et al. 1996).

\section{Statistical analysis}

The CFU count data were compared among treatments with regression analysis using a quadratic regression, which best fitted the data. The frequencies of positive and negative strains for root colonization were compared among soil treatments with a Chi-square test, and those for growth promotion, phosphate solubilization, indole acetic acid production and resistance induction were compared with a Fischer's exact test. The growth promotion variables were compared among strains using ANOVA, except PH and SD, which were submitted to a Skott-Knott test, and NL and DMAP, which were submitted to a Dunn test by the Kruskal-Wallis non-parametric analysis. Homogeneity of variance was assessed by Cochran's Q test and normality by the Shapiro Wilk test. The AUDPC means among replicates were compared among bacterial strains and controls using the Skott-Knott test and a significance level of
5\%. All analyses were performed using ASSISTAT 7.7 beta (Silva and Azevedo 2016).

\section{Molecular characterization}

The genomic DNA of the bacterial strains selected in the second step of the growth promotion trials was extracted using the phenol-chloroform method adapted from Sambrook et al. (1989). We used the P027F (5'-GAGAGTTTGATCCTGGCTCAG-3') and 1492R (5'-ACGGTTACCTTGTTACGACTT-3') PCR primer pair (Weisburg et al. 1991) for the amplification of the $16 \mathrm{~S}$ rRNA region and the ERIC1F (5' ATGTAAGCTCCTGGGGATTCAG-3') and ERIC2R (5'-AAGTAAGTGACTGGGGTGAGC - 3') primer pair to evaluate strain diversity (Versalovic et al. 1991).

For the PCR reactions with both primers, the following concentrations were used: $100 \mathrm{ng}$ total DNA, 0.2 pmol of each primer, $1 \mathrm{X}$ enzyme buffer $(100 \mathrm{mM}$ Tris- $\mathrm{HCl}(\mathrm{pH} 8.8$ at $25^{\circ} \mathrm{C}$ )), $2 \mathrm{mM} \mathrm{MgCl}_{2}, 0.4 \mathrm{mM}$ dNTPs and 1.25 units of Taq DNA Polymerase. The reaction took place in a final volume of $25 \mu$ l. Amplification conditions included an initial denaturation at $95^{\circ} \mathrm{C}$ for $5 \mathrm{~min}, 35$ denaturation cycles at 94 ${ }^{\circ} \mathrm{C}$ for $1 \mathrm{~min}$, annealing at $50^{\circ} \mathrm{C}$ for $1 \mathrm{~min}$ and extension at $65^{\circ} \mathrm{C}$ for $8 \mathrm{~min}$, with a final extension at $65^{\circ} \mathrm{C}$ for $16 \mathrm{~min}$. At the end of the cycles, the reaction was maintained at 10 ${ }^{\circ} \mathrm{C} / \infty$. After amplification, fragments were separated in $1.5 \%$ agarose gel with electrophoresis and visualized (L-PIX CHEMI Molecular Imaging).

PCR products generated from the P027F/1492R primer pair were treated with polyethyleneglycol (20\% PEG) and sequenced using the BigDye ${ }^{\mathrm{TM}}$ Terminator v3.1 kit on the 3500 Genetic Analyzer (Applied Biosystems ${ }^{\mathrm{TM}}{ }^{\text {) }}$ ) according to the manufacturer's recommendations. The consensus sequence was obtained manually based on the sequencing of the $\mathrm{F}$ and $\mathrm{R}$ strands, and new sequences generated in this study were deposited in GenBank (http://www.ncbi.nlm.nih) under accession numbers MH547253 to MH547275.

The results obtained from the ERIC1F/ERIC2R primer pair reaction were analyzed using the $\mathrm{PAST}^{\oplus}$ Program (version $2.17 \mathrm{c}$; Hammer et al. 2000), after binary data transformation and the construction of a $0-1$ matrix, where 1 indicates the presence, and 0 the absence of a band. The bands generated for each strain were compared and their similarities estimated by the Jaccard coefficient, which was obtained by the unweighted pair group method with arithmetic mean (UPGMA) algorithm, and the strains were grouped and plotted using a similarity dendrogram (Sneath and Sokal 1973).

Dataset construction was completed with 16S rRNA region sequences from the strains obtained in this study. Sequences were obtained from GenBank (http://www.ncbi. nlm.nih) using the BLASTn tool. The sequences were aligned 
with the MAFFT online service (Katoh et al. 2017) and manually adjusted in MEGA 7.0 (Tamura et al. 2013).

Phylogenetic analyses were performed using the maximum likelihood (ML) and Bayesian inference (BI) methods. Partial deletion was used for the treatment gaps and missing data in the ML analysis. The $95 \%$ cut off and non-parametric bootstrap measurements were done with 1000 replicates, and the tree was generated and visualized in MEGA 7.0. Bayesian inference was based on the model selected by PAUP* 4 and Mrmodeltest2 v2 (Posada 2003) through an alignment including all sites. The analysis was allowed to run for ten million generations, with the first $25 \%$ of trees discarded as burn-ins using the tool MrBayes v. 3.6, which is available on the CIPRES platform (https://www.phylo.org/). Posteriori probabilities (PP) and tree topologies were visualized with Figtree v. 1.1.2 (Rambaut 2009).

The identity analysis between the sequences was performed in the SDT v.1.2 program (Sequence Demarcation tool) by means of an array containing sequences of the strains obtained in this study and sequences obtained from GenBank (http: //www.ncbi.nlm.nih) by the BLASTn tool. The alignment MAFFT algorithm was selected to calculate the identity values, and the similarity of the phylogenetic relationships was estimated with the neighbor component using two cut off values, one at $99 \%$ and the other at $78 \%$. These cut-off values represent the species demarcation thresholds (Kim et al. 2014).

\section{RESULTS}

\section{Influence of biochar on the soil cultivable bacterial population}

There was a significant difference in CFU among treatments according to regression analysis. Biochar stimulated bacterial growth up to $34 \mathrm{tha}^{-1}$ and from there on a decrease was observed in the bacteria population (Figure 1). The estimated CFU for soil without biochar (dose 0) was $6.65 \mathrm{x}$ $10^{6} \mathrm{CFU} \mathrm{ml}{ }^{-1}$. The optimal dose of biochar estimated by the

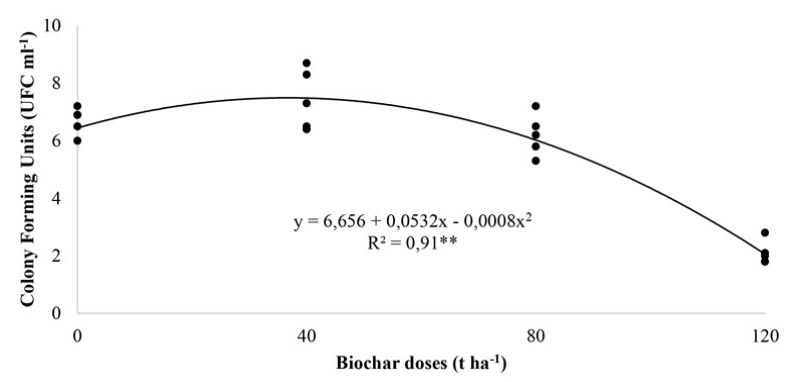

Figure 1. Relationship between biochar doses and colony forming units (CFU) of non-rhizospheric soil cultivable bacteria collected at the Experimental Station of Tropical Fruticulture - EEFT/INPA, municipality of Manaus (Amazonas, Brazil). ${ }^{* *}$ significant at $p \leq 0.01$. adjusted regression model was $34 \mathrm{tha}^{-1}$, providing a maximum value of $7.55 \times 10^{6} \mathrm{CFU} \mathrm{\textrm {ml } ^ { - 1 }}$. The adjusted regression model was $\hat{y}=6.656+0.0532 x-0.0008 x^{2}$, where $\hat{y}$ is the estimated $\mathrm{CFU}$ value and $\mathrm{x}$ the biochar dose. The model explained 91.4 $\%$ of the total CFU variation in response to biochar doses (Figure 1).

\section{Root colonization and growth promotion}

Seventy (35\%) of the initial 200 strains were positive for root colonization (Supplementary Material, Tables S1, S2), of which 53 were selected for the growth promotion test. Among the 53, eight (15\%) significantly reduced the growth of tomato seedlings relative to the controls, $20(37.7 \%)$ did not differ significantly from the control, and 25 had significantly higher DMAP (Supplementary Material, Table S3), and were considered the most promising bacterial strains. Among the 25 strains, SD differed significantly from the negative control in eight (32\%), DMR differed significantly in ten (40\%), and there was no significant difference in PH, DMAP and TDM (Table 2).

There was a significantly higher frequency of strains capable of colonizing the root system in the soils with 0 and $40 \mathrm{t} \mathrm{ha}^{-1}$ biochar $\left(\chi^{2}=28.92 ; p<0.0001\right)$ (Supplementary Material, Table S2). The frequency distribution of the bacterial strains positive for growth promotion did not vary significantly among soil types (Fisher's $\mathrm{p}=0.71709$ ) (Supplementary Material, Table S4), i.e., the strains responded in the same way to the growth promotion test, independently of the biochar dose.

\section{Indoleacetic acid production and phosphate solubilization}

Eighteen of the 25 strains were found to produce IAA, while only two showed calcium phosphate solubilization capacity: 25T4 and 12T4 (Table 2). These strains formed a solubilization halo and were categorized as precocious, with a low capacity to solubilize phosphate $(\mathrm{SI}<2)$. The two strains were from the treatment with $120 \mathrm{t} \mathrm{ha}^{-1}$ biochar, resulting in a relative frequency of $66.7 \%$ positive strains for solubilization of inorganic phosphate in the form of $\mathrm{CaHPO}_{4}$ (Supplementary Material, Table S5). Accordingly, the frequency distribution of strains positive for phosphate solubilization varied significantly among soil types (Fisher's $p=0.01$ ), i.e., there was an influence of the dose of biochar on the population of phosphate solubilizing bacteria present in non-rhizospheric soil (Supplementary Material, Table S5). It is worth mentioning that only in the soil with the highest dose of biochar $\left(120 \mathrm{tha}^{-1}\right)$ were found rhizobacteria belonging to the B. megaterium group (strain 25T4; Supplementary Material, Table S6) capable of solubilizing calcium phosphate in inorganic form.

The frequency distribution of the bacterial strains positive for production of indole acetic acid did not vary significantly 
Table 2. Results of growth promotion, production of indoleacetic acid and phosphate solubilization tests with 25 bacterial strains obtained from biochar-enriched nonrhizospheric soil collected at the Experimental Station of Tropical Fruticulture-EEFT/INPA, Manaus municipality (Amazonas, Brazil), on Santa Cruz Kada tomato seedlings 20 days after sowing on Vivato plus ${ }^{\circledast}$ substrate. Values are the mean \pm SD of 10 replicates. IAA and P indicate positive (+) or negative $(-)$ result for the production and solubilization test, respectively. CV\% = coefficient of variation.

\begin{tabular}{|c|c|c|c|c|c|c|c|c|c|c|c|c|}
\hline Strain & $\mathrm{PH}^{1}(\mathrm{~cm})$ & GPE (\%) & $\mathrm{SD}^{1}(\mathrm{~mm})$ & GPE (\%) & $\operatorname{DMAP}^{1}(\mathrm{~g})$ & GPE (\%) & $\operatorname{DMR}^{1}(\mathrm{~g})$ & GPE (\%) & $\operatorname{TDM}^{1}(\mathrm{~g})$ & GPE (\%) & IAA & $\mathrm{P}$ \\
\hline C-* & $12.5 \pm 0.5^{a}$ & 0.0 & $1.8 \pm 0.2^{b}$ & 0.0 & $0.0 \pm 0.04^{a}$ & 0.0 & $0.0 \pm 0.004^{b}$ & 0.0 & $0.0 \pm 0.05^{\mathrm{a}}$ & 0.0 & - & - \\
\hline$C+{ }^{* *}$ & $13.5 \pm 0.4^{\mathrm{a}}$ & 8.6 & $2.1 \pm 0.2^{a}$ & 13.0 & $0.1 \pm 0.06^{a}$ & 35.7 & $0.0 \pm 0.007^{a}$ & 75 & $0.1 \pm 0.06^{a}$ & 39.1 & + & - \\
\hline $3 \mathrm{~T} 4$ & $13.3 \pm 0.4^{\mathrm{a}}$ & 6.7 & $2.1 \pm 0.2^{\mathrm{a}}$ & 12.0 & $0.0 \pm 0.05^{\mathrm{a}}$ & 19.0 & $0.0 \pm 0.005^{b}$ & 25 & $0.0 \pm 0.05^{\mathrm{a}}$ & 19.6 & + & - \\
\hline $4 T 2$ & $12.9 \pm 0.3^{\mathrm{a}}$ & 3.6 & $2.1 \pm 0.1^{a}$ & 11.3 & $0.0 \pm 0.05^{\mathrm{a}}$ & 16.7 & $0.0 \pm 0.007^{a}$ & 75 & $0.1 \pm 0.06^{a}$ & 23.9 & - & - \\
\hline $6 \mathrm{~T} 1$ & $12.7 \pm 0.4^{\mathrm{a}}$ & 1.6 & $1.8 \pm 0.3^{b}$ & -2.7 & $0.0 \pm 0.04^{\mathrm{a}}$ & 7.1 & $0.0 \pm 0.005^{b}$ & 25 & $0.0 \pm 0.05^{\mathrm{a}}$ & 10.8 & + & - \\
\hline $15 \mathrm{~T} 2$ & $12.4 \pm 0.3^{\mathrm{a}}$ & -0.8 & $1.7 \pm 0.2^{b}$ & -9.2 & $0.0 \pm 0.04^{\mathrm{a}}$ & -9.5 & $0.0 \pm 0.007^{a}$ & 75 & $0.0 \pm 0.04^{\mathrm{a}}$ & -2.2 & + & - \\
\hline $25 \mathrm{~T} 4$ & $13.2 \pm 0.2^{\mathrm{a}}$ & 5.7 & $1.9 \pm 0.3^{b}$ & 0.5 & $0.0 \pm 0.05^{a}$ & 19.0 & $0.0 \pm 0.008^{a}$ & 100 & $0.1 \pm 0.06^{\mathrm{a}}$ & 28.3 & + & + \\
\hline $22 \mathrm{~T} 3$ & $13.5 \pm 0.3^{\mathrm{a}}$ & 8.7 & $2.0 \pm 0.3^{a}$ & 8.6 & $0.0 \pm 0.05^{a}$ & 21.4 & $0.0 \pm 0.009^{a}$ & 125 & $0.1 \pm 0.06^{\mathrm{a}}$ & 32.6 & - & - \\
\hline 53T1 & $13.3 \pm 0.3^{a}$ & 7.1 & $2.2 \pm 0.1^{a}$ & 17.3 & $0.0 \pm 0.05^{a}$ & 21.4 & $0.0 \pm 0.007^{a}$ & 75 & $0.1 \pm 0.06^{a}$ & 26.0 & + & - \\
\hline $23 \mathrm{~T} 3$ & $12.7 \pm 0.2^{\mathrm{a}}$ & 1.9 & $1.8 \pm 0.1^{b}$ & 1.1 & $0.0 \pm 0.04^{\mathrm{a}}$ & 0.0 & $0.0 \pm 0.008^{a}$ & 100 & $0.0 \pm 0.05^{\mathrm{a}}$ & 10.9 & + & - \\
\hline $52 \mathrm{~T} 1$ & $12.8 \pm 0.4^{\mathrm{a}}$ & 2.6 & $1.8 \pm 0.3^{b}$ & -2.2 & $0.0 \pm 0.04^{a}$ & 0.0 & $0.0 \pm 0.008^{a}$ & 100 & $0.0 \pm 0.05^{a}$ & 8.7 & - & - \\
\hline 114T1 & $12.8 \pm 0.5^{\mathrm{a}}$ & 2.4 & $1.9 \pm 0.4^{b}$ & 0.5 & $0.0 \pm 0.05^{\mathrm{a}}$ & 11.9 & $0.0 \pm 0.006^{b}$ & 50 & $0.0 \pm 0.05^{\mathrm{a}}$ & 16.7 & + & - \\
\hline $113 \mathrm{~T} 1$ & $12.9 \pm 0.2^{\mathrm{a}}$ & 3.3 & $2.0 \pm 0.2^{\mathrm{a}}$ & 7.0 & $0.0 \pm 0.05^{\mathrm{a}}$ & 14.3 & $0.0 \pm 0.007^{a}$ & 75 & $0.0 \pm 0.05^{\mathrm{a}}$ & 19.6 & + & - \\
\hline $117 \mathrm{~T} 1$ & $12.6 \pm 0.3^{\mathrm{a}}$ & 1.4 & $1.8 \pm 0.2^{b}$ & -0.5 & $0.0 \pm 0.04^{\mathrm{a}}$ & 0.0 & $0.0 \pm 0.004^{b}$ & 0.0 & $0.0 \pm 0.05^{\mathrm{a}}$ & 2.2 & + & - \\
\hline 47T1 & $13.1 \pm 0.3^{\mathrm{a}}$ & 5.5 & $1.9 \pm 0.3^{b}$ & 1.6 & $0.0 \pm 0.04^{\mathrm{a}}$ & 4.8 & $0.0 \pm 0.004^{b}$ & 0.0 & $0.0 \pm 0.05^{\mathrm{a}}$ & 2.2 & - & - \\
\hline $8 \mathrm{~T} 2$ & $12.6 \pm 0.4^{\mathrm{a}}$ & 1.2 & $1.8 \pm 0.3^{b}$ & 0.0 & $0.0 \pm 0.04^{\mathrm{a}}$ & 4.8 & $0.0 \pm 0.004^{b}$ & 0.0 & $0.0 \pm 0.05^{\mathrm{a}}$ & 2.2 & + & - \\
\hline $46 \mathrm{~T} 1$ & $12.1 \pm 0.4^{\mathrm{a}}$ & -3.1 & $1.9 \pm 0.2^{b}$ & 0.5 & $0.0 \pm 0.04^{\mathrm{a}}$ & 4.8 & $0.0 \pm 0.004^{b}$ & 0.0 & $0.0 \pm 0.05^{\mathrm{a}}$ & 4.3 & + & - \\
\hline $6 \mathrm{T3}$ & $11.7 \pm 0.3^{\mathrm{a}}$ & -5.8 & $1.8 \pm 0.2^{b}$ & -2.2 & $0.0 \pm 0.04^{a}$ & 7.1 & $0.0 \pm 0.005^{b}$ & 25 & $0.0 \pm 0.05^{\mathrm{a}}$ & 6.5 & - & - \\
\hline $30 \mathrm{~T} 2$ & $13.2 \pm 0.4^{\mathrm{a}}$ & 5.7 & $2.0 \pm 0.3^{a}$ & 5.9 & $0.0 \pm 0.04^{\mathrm{a}}$ & 4.8 & $0.0 \pm 0.004^{b}$ & 0.0 & $0.0 \pm 0.05^{\mathrm{a}}$ & 6.5 & + & - \\
\hline $80 T 2$ & $12.8 \pm 0.3^{a}$ & 2.7 & $2.0 \pm 0.2^{a}$ & 9.7 & $0.0 \pm 0.05^{a}$ & 14.3 & $0.0 \pm 0.004^{b}$ & 0.0 & $0.0 \pm 0.05^{a}$ & 13.0 & + & - \\
\hline $28 \mathrm{~T} 2$ & $12.5 \pm 0.3^{\mathrm{a}}$ & 0.1 & $1.8 \pm 0.3^{b}$ & -1.1 & $0.0 \pm 0.04^{a}$ & 4.8 & $0.0 \pm 0.004^{b}$ & 0.0 & $0.0 \pm 0.05^{\mathrm{a}}$ & 4.3 & - & - \\
\hline $2 \mathrm{~T} 2$ & $12.5 \pm 0.3^{a}$ & 0.2 & $1.9 \pm 0.2^{b}$ & 0.5 & $0.0 \pm 0.04^{a}$ & -2.4 & $0.0 \pm 0.004^{b}$ & 0.0 & $0.0 \pm 0.04^{a}$ & -2.2 & + & - \\
\hline $115 \mathrm{~T} 1$ & $13.0 \pm 0.2^{\mathrm{a}}$ & 4.5 & $1.9 \pm 0.3^{b}$ & 2.2 & $0.0 \pm 0.04^{a}$ & 7.1 & $0.0 \pm 0.004^{b}$ & 0.0 & $0.0 \pm 0.05^{\mathrm{a}}$ & 6.5 & + & - \\
\hline $12 \mathrm{~T} 4$ & $12.7 \pm 0.2^{\mathrm{a}}$ & 2.3 & $1.8 \pm 0.3^{b}$ & -3.2 & $0.0 \pm 0.04^{\mathrm{a}}$ & -4.8 & $0.0 \pm 0.004^{b}$ & 0.0 & $0.0 \pm 0.04^{\mathrm{a}}$ & -4.3 & - & + \\
\hline $52 \mathrm{~T} 2$ & $13.1 \pm 0.3^{\mathrm{a}}$ & 4.8 & $1.9 \pm 0.2^{b}$ & 0.5 & $0.0 \pm 0.05^{a}$ & 14.3 & $0.0 \pm 0.005^{b}$ & 25 & $0.0 \pm 0.05^{\mathrm{a}}$ & 13.0 & + & - \\
\hline
\end{tabular}

1 Means followed by the same letter in the column do not differ significantly from each other based on the Scott-Knott test ( $p<0.05)$.

* Negative control; ** Positive control.

among soil types (Fisher's $\mathrm{p}=0.8602$ ) (Supplementary Material, Table S7).

\section{Biological control}

Eleven of the 25 strains did not differ statistically from the controls containing only the pathogen. Other 11 had positive results that were statistically equivalent to the positive control, and three had the most promising results, with AUDPC significantly below the positive control (Figure 2), and percentage of protection between 50 and 59\% (Figure 3). There was no difference among the soil types in the frequency of bacterial strains with potential to induce resistance (Fisher's $\mathrm{p}=0.5537$ ) (Supplementary Material, Table S8), i.e., the strains from different soils responded in the same way to the resistance induction test, with no influence of the biochar doses on the result.

\section{Molecular characterization}

Of the 25 selected strains, 23 16S-rRNA regions were sequenced successfully. The phylogenetic analysis of 25 sequences was based on 1354 characters, including gaps, of which 30 were obtained from GenBank. The analysis was performed using the best-selected evolutionary model (HKY $+\mathrm{G})$. The topology of the tree obtained was derived from the ML analysis plus the posterior probability values in the main branches containing three genera of the Bacillaceae family with twenty-one taxa (Figure 4). Of the 23 strains obtained, 20 were characterized as Bacillus, 17 belonged to the Cereus group, and three were characterized as Lysinibacillus, more closely related to Lysinibacillus sphaericus and Lysinibacillus macroides. Among the strains of the genus Bacillus that do not belong to the $B$. cereus group, 46T1 was more closely related to Bacillus altitudinis, and 25T4 and 12T4 to Bacillus megaterium, all with a high level of statistical support.

Based on the pairwise identity data (Figure 5), strain $114 \mathrm{~T} 1$ showed $>99 \%$ identity with L. sphaericus and $L$. 


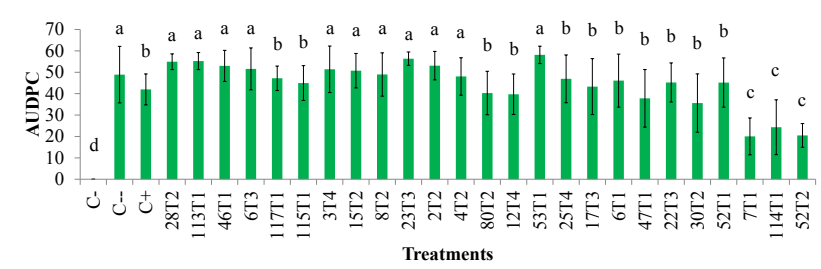

Figure 2. Mean values of the area under the target spot progression curve (AUDPC) by the diagrammatic scale in Santa Cruz Kada tomato seedlings, for 25 beneficial bacterial strains and three controls ( $\mathrm{C}-=$ only water; $\mathrm{C}--=$ no strain + pathogen; $\mathrm{C}+=$ Bacillus cereus UFV 121). Columns represent the mean and bars the standard deviation. Same letters above the means indicate non-significant differences by the Skott-Knott test. This figure is in color in the electronic version.
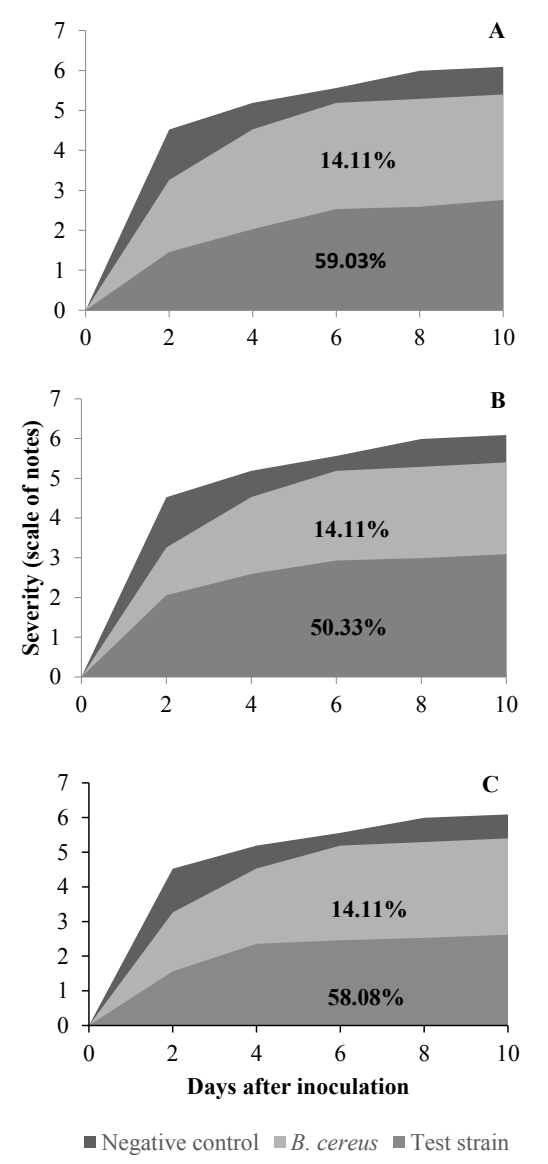

Figure 3. Progress of target spot and protection percentage (values in the boxes) in Santa Cruz Kada cv. tomato seedlings for three beneficial bacterial strains collected from biochar-enriched non-rhizospheric soil at the Experimental Station of Tropical Fruticulture - EEF /INPA, municipality of Manaus (Amazonas, Brazil) A - strain $7 \mathrm{~T} 1 ; \mathrm{B}-\operatorname{strain} 114 \mathrm{~T} 1 ; \mathrm{C}-\mathrm{strain} 52 \mathrm{~T} 2$.

macroides. Strains with identity $>99 \%$ belonging to the Bacillus clade were grouped in the Cereus group. Strains 8T2 and 3T4 were more closely related to Bacillus thuringiensis, and $6 \mathrm{~T} 3$ and $30 \mathrm{~T} 2$ to B. cereus. Five strains shared a $98 \%$ identity, and thirteen shared a $<97 \%$ identity (Supplementary Material, Table S6).

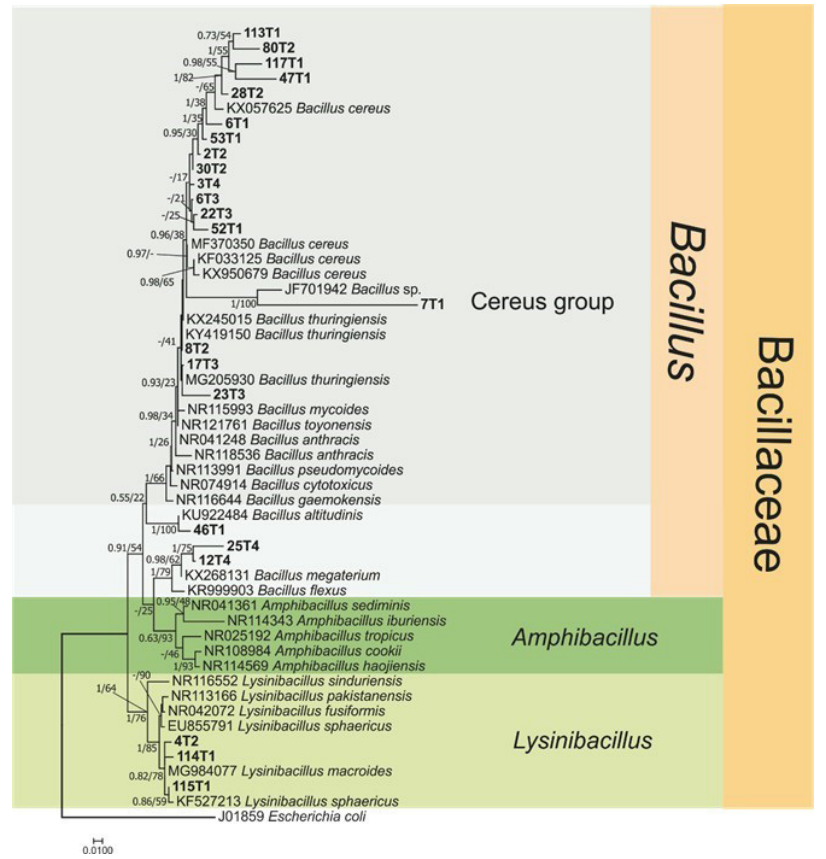

Figure 4. Phylogram resulting from a consensus of maximum likelihood and Bayesian analysis based in 16S rRNA region alignment, with the values of bootstrap and posteriori probability (ML/PP) for 25 beneficial bacterial strains obtained in this study from biochar-enriched non-rhizospheric soil collected at the Experimental Station of Tropical Fruticulture - EEFT/INPA, municipality of Manaus (Amazonas, Brazil). Test strains are marked in bold. The tree is rooted with Escherichia coli strain J01859. This figure is in color in the electronic version.

The dendrogram generated from ERIC-PCR had low similarity coefficients in some of the formed groups. Four main groups were formed, with their respective subgroups. Group I was subdivided into three subgroups. Strain 46T1 (subgroup Ia), which was identified as Bacillus sp. (pumilus group), did not group directly with the other strains of group I, corroborating the identification by sequencing of the $16 \mathrm{~S}$ rRNA gene. Subgroups Ib, Ic and Id were composed exclusively of strains from group $B$. cereus. It is noteworthy that strains $17 \mathrm{~T} 3$ and $22 \mathrm{~T} 3$ showed the formation of only one band and two bands, respectively, which did not allow their correct grouping in the dendrogram, and provided low coefficients of similarity that do not corroborate the information obtained by sequencing the $16 \mathrm{~S}$ rRNA gene (Figure 6).

Two strains, 3T4 and 4T2, were allocated into group II and identified as Bacillus sp. group B. cereus and Lysinibacillus sp., respectively. This group differed most from the others, as they grouped in the same clade and belonged to different genera, which differs from the information obtained from the 16S rRNA gene sequencing (Figure 6).

Group III was divided into two subgroups, both containing only Bacillus strains. In subgroup IIIa, only strains belonging to the group $B$. cereus were grouped, with two groupings (53T1-80T2 and 15T2-6T3) with 100\% similarity 


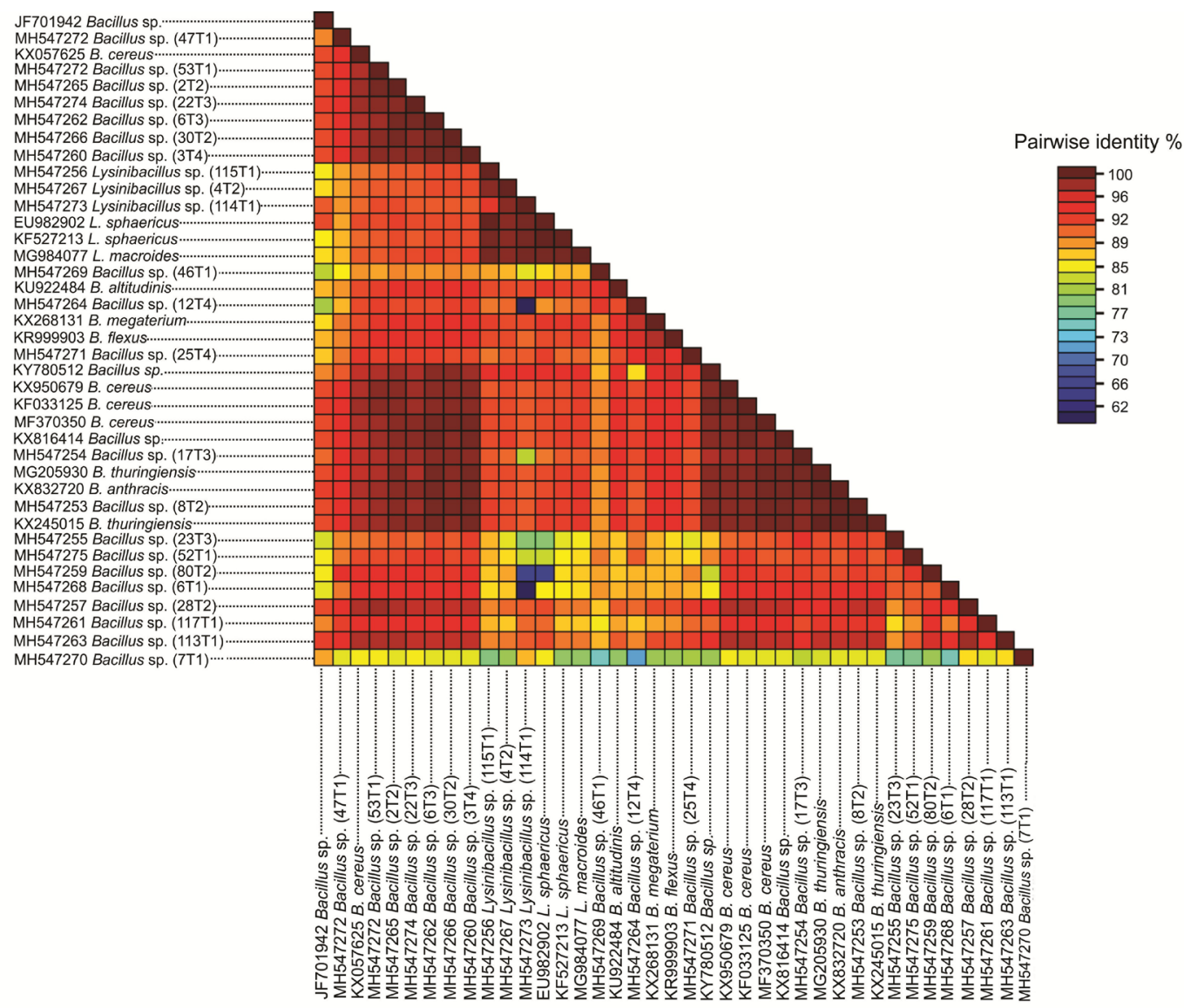

Figure 5. Colour-coded pairwise identity matrix generated from 39 sequences of the $16 \mathrm{~S}$ rRNA region of 25 beneficial bacterial strains obtained from biochar-enriched non-rhizospheric soil collected at the Experimental Station of Tropical Fruticulture - EEFT/INPA, municipality of Manaus (Amazonas, Brazil). Each colored cell represents an identity percentage score between two sequences indicated horizontally to the left and vertically at the bottom. A colored key indicates the correspondence between pairwise identities and the colors displayed in the matrix. The strains obtained in this study are identified in parentheses. This figure is in color in the electronic version.

among the strains. Strains $25 \mathrm{~T} 4$ and $12 \mathrm{~T} 4$, both identified as Bacillus spp. (megaterium group), also grouped (70\% similarity) into subgroup IIIb, as observed in the phylogenetic analysis (Figure 6).

Group IV presented two subdivisions (IVa and IVb). Subgroup IVa only included strains of group B. cereus. Subgroup IVb formed two sub-subgroups (IVb.1 and IVb.2). Only strain 7T1 (group B. cereus) was allocated to sub-subgroup IVb.1, and strains $115 \mathrm{~T} 1$ and 114T1, both identified as Lysinibacillus sp.with $85 \%$ similarity coefficient, were allocated to sub-subgroup IVb.2, corroborating the phylogeny based on $16 \mathrm{~S}$ rRNA sequencing (Figure 6).

\section{DISCUSSION}

Our results suggest that biochar enhancement in higher doses reduces the population of cultivable bacteria in nonrhizospheric soil and intere negatively with the survival of bacterial groups capable of actively colonizing the rhizosphere of tomato seedlings, while having beneficial effects on bacteria of the $B$. megaterium group capable of solubilizing phosphate. However, no selective effect of biochar dose was observed

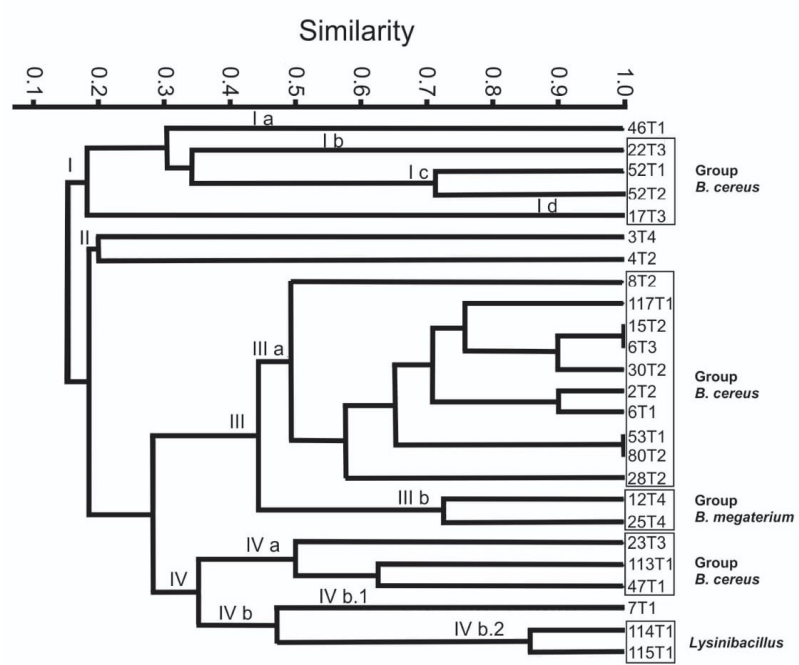

Figure 6. Dendrogram generated by the UPGMA cluster, based on the Jaccard coefficient of similarity, from the analysis of polymorphic bands generated by Eric-PCR of 25 beneficial bacterial strains obtained from biochar-enriched nonrhizospheric soil collected at the Experimental Station of Tropical Fruticulture - EEFT/INPA, municipality of Manaus (Amazonas, Brazil). 
on rhizobacteria capable of producing indole acetic acid or promoting growth or inducing resistance against $C$. cassiicola in tomato seedlings.

Despite the negative effects of higher doses of biochar on bacterial populations in general, and on bacteria capable of root colonization in particular, observed in this study, there are a few studies reporting the influence of biochar on specific groups of rhizobacteria that are capable of forming effective plant-rhizobacterial associations that provide plant growth (e.g. Egamberdieva et al. 2016; Nadeem et al. 2017; Ren et al. 2020). Therefore, more studies are necessary, testing a wider range of strains and experimental designs with more independent replicates for each treatment level, in order to further evaluate the effects of biochar enhancement on growthpromoting bacteria for tomato seedlings.

Biochar amendments increase the population densities of soil bacteria and actinomycetes, modify soil fungi/bacteria and fungi/actinomycetes ratios and increase soil microbial activity (Lu et al. 2016). However, higher rates may not be beneficial and can even become detrimental (Zwart and Kim 2012), which seems to have occurred in the soil analyzed here, as our results pointed to an optimal dosage for bacterial development below that of the lowest experimental biochar concentration. The dosage and type of biochar added to the soil can influence the morphology and topography of biofilms, as the binding force, or even biochar colonization, depends on the type of dominant molecule readily available on the surface of the biochar (e.g., phenolic components, silica and metal oxides). These act as chemical signals that induce cell lysis and biofilm formation, and promote interaction pathways that condition the adaptation and survival of bacterial species (Bueno et al. 2018). For example, the growth rate of Bacillus subtilis SL-13 in NB medium increased with the addition of biochar, because it contains nutrients for the growth of these bacteria and the special porous structure of the biochar has a positive effect on the adsorption of bacteria, being a potentially suitable carrier of PGPR for agriculture (Tao et al. 2018).

Molecular analysis showed that the three most promising strains for biological control are species of Bacillus (Cereus group) and Lysinibacillus, and those that showed the best results for growth promotion belong to Bacillus. A study in greenhouse conditions demonstrated that maize plants inoculated with B. subtilis and Lysinibacillus fusiformis in biochar-enhanced substrate presented better growth and nutrient concentration than biochar and bacterial treatments alone (Rafique et al. 2017). These improvements in plant growth were mainly attributed by the authors to phosphate-solubilization by the bacterial strains in the soil, phosphate from the biochar and IAA, cytokinin and gerbilline production.

Bacillus thuringiensis inhibited the growth of the $C$. cassiicola in-vitro and in-planta (Giau and Quoc 2017).
The production of antimicrobial lipopeptides synthesized in a nonribosomal mode is one of the possible means for Bacillus strains to use their antimicrobial action (Almoneafy et al. 2014). The fresh and dry mass of tomato plants were also enhanced by Bacillus strains (Almoneafyet al. 2014). Bacillus sp., B. amiloliquefaciens, B. pumilus and B. subtilis significantly increased the length, pseudostem diameter, fresh mass and dry mass in Prata Anã banana seedlings (Souza et al. 2017). Plant growth was also increased when a L. sphaericus strain was inoculated on Trigonella feonum-graecum (methi) and Vigna radiata (mung beans) seeds (Sharma and Saharan 2015). Genes coding for secondary metabolites, such as bacillibactin, bacilysin, microcin, bacillaene, difficidin, fengycin, macrolactin and surfactin, were found in bacterial strains that promoted plant growth and controlled multiple diseases (Liu et al. 2017), showing that mechanisms of growth promotion and plant protection may be genetically mediated.

The distribution based on pairwise identity corroborated the data obtained by phylogenetic analyses (ML and $\mathrm{BI}$ ) for strain identification. However, for the Lysinibacillus clade, the relationship between $L$. sphaericus and L. macroides, which showed identity $>99 \%$, was not well defined, making identification difficult through the $16 \mathrm{~S}$ region due to the high homology between these taxa. For the genus Bacillus, the 16S region also had a low phylogenetic resolution (Janda et al. 2007). The $16 S$ sequencing method has limitations, as in the closely related Bacillus anthracis, B. cereus and B. thuringiensis, which have identical $16 \mathrm{~S}$ rDNA sequences, making their differentiation difficult using only this barcode (Han 2006) .

Strains that showed the highest identity with $B$. cereus and $B$. thuringiensis responded to the clustering tendency observed both in the pairwise identity analysis by the neighbor component and in the phylogenetic inferences, despite the low support of PP and bootstrap. According to Petti (2007), an identity of $<97 \%$ may indicate the existence of a new species.

\section{CONCLUSIONS}

The Cereus group responded more than other rhyzobacteria to the dosages of biochar used in this study. Three strains showed potential for promoting growth: 7T1, with the highest GPE for DMAP; 22T3, with the highest GPE for PH, DMR and TDM; and 53T1, with the highest GPE for SD. The 7T1, $114 \mathrm{~T} 1$ and 52T 2 strains showed potential for biological control, presenting the lowest AUCPD. 7T1 stood out for being beneficial for both growth promotion and biological control against $C$. cassiicola and is recommended for future studies. Furthermore, some strains were capable of solubilizing phosphate and producing IAA. Strains that presented high growth promotion efficiency and reduced the severity of target spot in tomato seedlings have the potential for use as additional tools for the integrated management of this disease. 


\section{ACKNOWLEDGMENTS}

The authors would like to thank the Fundação de Amparo à Pesquisa do Estado do Amazonas (FAPEAM) for the financial assistance.

\section{REFERENCES}

Agrofit. 2020. Ministério da Agricultura, Pecuária e Abastecimento. (http://agrofit.agricultura.gov.br/agrofit_cons/principal_agrofit_ cons). Accessed on 05 Feb 2020.

Ahmed, I.; Yokota, A.; Yamazoe, A.; Fujiwara, T. 2007. Proposal of Lysinibacillus boronitolerans gen. nov. sp. nov., and transfer of Bacillus fusiformis to Lysinibacillus fusiformis comb. nov. and Bacillus sphaericus to Lysinibacillus sphaericus comb. nov. International Journal of Systemic and Evolutionary Microbiology, 57: 1117-1125.

Almoneafy, A.A.; Kakar, K.U.; Nawaz, Z.;Li, B; Ali Saand, M; Chunlan, Y.; Xie, G-L. 2014. Tomato plant growth promotion and antibacterial related-mechanisms of four rhizobacterial Bacillus strains against Ralstonia solanacearum. Symbiosis, 63: 59-70.

Antonius, S.; Dewi, T.K.; Osaki, M. 2015. The synergy of biochar, compost and biofertilizer for development of sustainable agriculture. KnE Life Sciences, 2: 677-681.

Asit, K .M.; Praveen, K.M.; Subrata, D.; Arup, C. 2017. Effective Management of Major Tomato Diseases in the Gangetic Plains of Eastern India through Integrated Approach. Agricultural Research and Technology, 10: 555796. DOI: 10.19080/ ARTOAJ.2017.10.555796

Berraquero, F.R.; Baya, A.M.; Cormenzana, A.R. 1976. Establecimiento de indices para el estudio de la solubilizacion de fosfatos por bacterias del suelo. Ars Pharmaceutica, 17: 399-406.

Bertola, M.; Mattarozzi, M.; Sanangelantoni, A.M.; Careri, M.; Visioli, G. 2019. PGPB colonizing three-year biochar-amended soil: towards biochar-mediated biofertilization. Journalof Soil Science and Plant Nutrition, 19: 1-10.

Bric, J.M.; Bostock, R.M.; Silverstone, S.E. 1991. Rapid in situ assay for indoleacetic acid production by bacteria immobilized on a nitrocellulose membrane. Applied and Environmental Microbiology, 57: 535-538.

Bueno, C.C.; Fraceto, L.F.; Rosa, A.H. 2018. Biochar influence the production and release of exopolysaccharides on plant growth promoting bacteria. Chemical Engineering Transactions, 65: 823-828.

Campbell, R.; Greaves, M.P. 1990. Anatomy and community structure of the rhizosphere. In: Lynched, J.M. (Ed). The Rhizosphere. John Wiley \& Sons, Chichester, p.11-34.

Cerri, C.E.P.; Coleman, K.; Jenkinson, D.S.; Bernoux, M.; Victoria, R.L.; Cerri, C.C. 2003. Soil carbon dynamics at Nova Vida Ranch, Amazon, Brazil. Soil Science Society of America Journal, 67: 1879-1887.

Chaturvedi, M.; Sharma, C.; Chaturvedi, M. 2013. Effects of pesticides on human beings and farm animals: acase study. Research Journal of Chemical and Environmental Sciences, 1: 14-19.

Dixon, L.J.; Schlub, R.L.; Pernezny, K.; Datnoff, L.E. 2009. Host specialization and phylogenetic diversity of Corynespora cassiicola. Phytopathology, 99: 1015-1027.

Egamberdieva, D.; Wirth, S.; Behrendt, U.; Abd Allah, E.F.; Berg, G. 2016. Biochar treatment resulted in a combined effect on soybean growth promotion and a shift in plant growth promoting rhizobacteria. Frontiers in Microbiology, 7: 209. doi: 10.3389/ fmicb.2016.00209.

Elad, Y.; David, D.R.; Harel, Y.M.; Borenshtein, M.; Kalifa, H.B.; Silber, A.; Graber, E.R. 2010. Induction of systemic resistance in plants by biochar, a soil-applied carbon sequestering agent. Phytopathology, 100: 913-921.

Faostat. 2017. Food and Agriculture Organization of the United Nations. (http://www.fao.org/faostat/en/\#data/QC). Accessed on 05 Feb 2020.

Giau, P.T.N.; Quoc, N.B. 2017. Biological control of Corynespora cassiicola causing corynespora leaf fall disease (CLF) on rubber tree by Bacillus thuringiensis (T3). Proceedings of the International Rubber Conference, 2017: 459-476. (http://ejournal.puslitkaret. co.id/index.php/proc/article/view/472). Accessed on $15 \mathrm{Jan}$ 2020.

Hammer, O.; Harper, D.A.T.; Ryan, P.D. 2000. Past, v. 2.17c. Palaeontologia Electronica, 4: 1-229.

Han, X.Y. 2006. Bacterial identification based on 16 S ribosomal RNA gene sequence analysis. In: Tang, Y.-W.; Stratton, C. (Ed.). Advanced Techniques in Diagnostic Microbiology, Springer, New York, p.323-332.

Hara, F.A.S.; Oliveira, L.A. 2004. Características fisiológicas e ecológicas de isolados de rizóbios oriundos de solos ácidos e álicos de Presidente Figueiredo, Amazonas. Acta Amazonica, 34: 343-357.

Jaiswal, A.K.; Elad, Y.; Graber, E.R.; Cytryn, E.; Frenkel, O. 2018. Soil-borne disease suppression and plant growth promotion by biochar soil amendments and possible mode of action. Acta Horticulturae, 1207: 69-76.

Janda, J.M.; Abbott, S.L. 2007. 16S rRNA gene sequencing for bacterial identification in the diagnostic laboratory: pluses, perils, and pitfalls. Journal of Clinical Microbiology, 45: 2761-2764.

Kado, C.I.; Heskett, M.G. 1970. Selective media for isolation of Agrobacterium, Corynebacterium, Erwinia, Pseudomonas and Xanthomonas. Phytopathology, 60: 969-976.

Katoh, K.; Rozewicki, J.; Yamada, K.D. 2017. MAFFT online service: multiple sequence alignment, interactive sequence choice and visualization. Briefings in Bioinformatics, 2017: 1160-1166.

Katznelson, H.; Bose, B. 1959. Metabolic activity and phosphatedissolving capability of bacterial isolates from wheat root, rhizosphere and non-rhizosphere soil. Canadian Journal of Microbiology, 5: 79-85.

Khalifa, W.; Thabet, M. 2015. Biochar amendment enhances tomato resistance to some soil borne diseases. Middle East Journal of Agriculture Research, 4: 1088-1100.

Kim, M.; Oh, H.S.; Park, S.C.; Chun, J. 2014. Towards a taxonomic coherence between average nucleotide identity and 16S rRNA gene sequence similarity for species demarcation of prokaryotes. International Journal of Systematic and Evolutionary Microbiology, 64: 346-351.

Li, J.; Zingen-Sell, I.; Buchenauer, H. 1996. Induction of resistance of cotton plants toVerticilliumwilt and of tomato plants toFusarium wilt by b-aminobutyric acid and methyl jasmonate. Journal of Plant Diseases and Protection, 103: 288-299.

Liu, K.; Newman, M.; McInroy, J.A.; Hu, C.H.; Kloepper, J.W. 2017. Selection and assessment of plant growth-promoting rhizobacteria for biological control of multiple plant diseases. Phytopathology, 107: 928-936.

Lu, Y.; Rao, S.; Huang, F.; Cai, Y.; Wang, G.; Cai, K. 2016. Effects of biochar amendment on tomato bacterial wilt resistance and 
soil microbial amount and activity. International Journal of Agronomy, 2016: 2938282.

Nadeem, S.M.; Imran, M.; Naveed, M.; Khan, M.Y.; Ahmad, M.; Zahir, Z.A.; Crowley, D.E. 2017. Synergistic use of biochar, compost and plant growth-promoting rhizobacteria for enhancing cucumber growth under water deficit conditions. Journal of the Science of Food and Agriculture, 97: 5139-5145.

Naureen, Z.; Rehman, N.U.; Hussain, H.; Hussain, J.; Gilani, S.A.; Housni, S.K. Al.; et al. 2017. Exploring the potentials of Lysinibacillus sphaericus ZA9 for plant growth promotion and biocontrol activities against phytopathogenic fungi. Frontiers in Microbiology, 8: 1477. doi: 10.3389/fmicb.2017.01477.

Oliveira, A.L.M.; Canuto, E.L. de; Urquiaga, S. 2006. Yield of micropropagated sugarcane varieties in different soil types following inoculation with diazotrophic bacteria. Plant and Soil, 284: 23-32.

Palansooriya, K.N.; Wong, J.T.F.; Hashimoto, Y.H.; Huang, L.; Rinklebe, J.; Chang, S.X.; Bolan, N.; Wang, H.; Ok, Y.S. 2019. Response of microbial communities to biochar-amended soils: A critical review. Biochar, 1: 3-22.

Petti, C.A. 2007. Detection and identification of microorganisms by gene amplification and sequencing. Clinical Infectious Diseases, 44: 1108-1114.

Posada, D. 2003. Using MODELTEST and PAUP* to select a model of nucleotide substitution. Current Protocols in Bioinformatics, 1: 6-5.

Rafique, M.; Sultan, T.; Ortas, I.; Chaudhary, H.J. 2017. Enhancement of maize plant growth with inoculation of phosphate-solubilizing bacteria and biochar amendment in soil. Soil Science and Plant Nutrition, 63: 460-469.

Rambaut, A. 2009. Tracer 1.5. (http://beast.bio.ed.ac.uk/Tracer). Accessed on 30 Jun 2020.

Rao, M.P.N.; Dong, Z.-Y.; Liu, G.-H.; Li, L.; Xiao, M.; Li, W.-J. 2019. Reclassification of Bacillus aryabhattai Shivaji et al. 2009 as a later heterotypic synonym of Bacillus megaterium de Bary 1884 (Approved Lists 1980), FEMS Microbiology Letters, 366: 1-3.

Ren, H.; Huang, B.; Fernández-García, V.; Miesel, J.; Yan, L.; Lv, C. 2020. Biochar and rhizobacteria amendments improve several soil properties and bacterial diversity. Microorganisms, 8: 502. doi: $10.3390 /$ microorganisms8040502.

Romeiro, R.S.; Lanna Filho, R.; Macagnan, D.; Garcia, F.A.O.; Silva, H.S.A. 2010. Evidence that the biocontrol agent Bacillus cereus synthesizes protein. Tropical Plant Pathology, 35: 11-15.

Sambrook, J.; Fritsch, E.F.; Maniatis, T. 1989. Molecular Cloning: a Laboratory Manual. Cold Spring Harbor, New York, 1626p.

Sharma, N.; Saharan, B.S. 2015. Role of Lysinibacillus sphaericus SNCh5 bacterial strain as bio-inoculant for agriculture practice.
International Journal of Current Microbiology and Applied Sciences, 4: 484-499.

Sneath, P.H.A.; Sokal, R.R. 1973. Numerical Taxonomy: The Principles and Practice of Numerical Classification. WF Freeman \& Company, San Francisco, 573p.

Silva, F.A.S.; Azevedo, C.A.V. 2016. The Assistat Software Version 7.7 and its use in the analysis of experimental data. African Journal of Agricultural Research, 11: 3733-3740.

Silva, H.S.A.; Romeiro, R.S.; Mounteer, A. 2003. Development of a root colonization bioassay for rapid screening of rhizobacteria for potential biocontrol agents. Journal of Phytopathology, 151: 42-46.

Silva, H.S.A.; Romeiro, R.S. 2004. Isolamento e seleção massal de rizobactérias indutoras de resistência sistêmica à manchabacteriana-pequena do tomateiro. Revista Ceres, 51: 345-354.

Souza, G.L.O.D. de; Silva, D.F. da; Silvia, N.; Xavier, A.A.; Pereira, M.C.T. 2017. Endophytic bacteria used as bioinoculants in micropropagated banana seedlings. Revista Brasileira de Fruticultura, 39: e-324.

Tamura, K.; Stecher, G.; Peterson, D.; Filipski, A.; Kumar, S. 2013. MEGA6: Molecular Evolutionary Genetics Analysis version 6.0. Molecular Biology and Evolution, 30: 2725-2729.

Tao, S.Y.; Wu, Z.S.; He, X.W.; Ye, B.C.; Li, C. 2018. Characterization of biochar prepared from cotton stalks as efficient inoculum carriers for bacillus subtilis SL-13. Bioresources, 13: 1773-1786.

Teramoto, A.; Meyer, M.C.; Suassuna, N.D.; Cunha, M.G. 2017. In vitro sensitivity of Corynespora cassiicola isolated from soybean to fungicides and field chemical control of target spot. Summa Phytopathologica, 43: 281-289.

Versalovic, J.; Koeuth, T.; Lupski, J.R. 1991. Distribution of repetitive DNA sequences in eubacteria and application to fingerprinting of bacterial genomes. Nucleic Acids Research, 19: 6823-6831.

Weisburg, W.G.; Barns, S.M.; Pelletier, D.A.; Lane, D.J. 1991. 16S ribosomal DNA amplification for phylogenetic study. Journal of Bacteriology, 173: 697-703.

Yabuuchi, E.; Kosako, Y.; Yano, I.; Hotta, H.; Nishiuchi, Y. 1996. Validation of the publication of new names and new combinations previously effectively published outside the IJBS. International Journal of Systematic Bacteriology, 46: 625-626.

Zwart, D.C.; Kim, S.H. 2012. Biochar amendment increases resistance to stem lesions caused by Phytophthora spp. in tree seedlings. Hort Science, 47: 1736-1740.

RECEIVED: $11 / 03 / 2019$

ACCEPTED: 25/09/2020

ASSOCIATE EDITOR: Antonio R. Fernandes 
ACTA

AMAZONICA

CANIATO et al. Bacteria from biochar-enhanced soil for tomato growth and disease control

SUPPLEMENTARY MATERIAL (only available in the electronic version)

Caniato et al. Diversity of bacterial strains in biochar-enhanced Amazon soil and their potential for growth promotion and biological disease control in tomato.

Table S1. Presence (+) or absence (-) of in vitro root colonization capacity of 200 bacterial strains from biochar-enriched Amazon soil in tomato seedlings, Santa Cruz Kada cultivar.

\begin{tabular}{|c|c|c|c|c|c|c|c|}
\hline & \multirow[b]{2}{*}{ Strain } & \multirow[b]{2}{*}{ Colonization } & & & \multirow[b]{2}{*}{ Colonization } \\
\hline Strain & Colonization & & & Strain & Colonization & Strain & \\
\hline $1 \mathrm{~T} 1$ & - & $1 \mathrm{~T} 2$ & + & $1 T 3$ & - & $1 \mathrm{~T} 4$ & - \\
\hline $2 \mathrm{~T} 1$ & - & $2 \mathrm{~T} 2$ & + & $2 T 3$ & - & $2 \mathrm{~T} 4$ & - \\
\hline $3 \mathrm{~T} 1$ & + & $3 \mathrm{~T} 2$ & + & $3 \mathrm{~T} 3$ & - & $3 \mathrm{~T} 4$ & + \\
\hline $4 \mathrm{~T} 1$ & + & $4 \mathrm{~T} 2$ & + & $4 \mathrm{~T} 3$ & - & $4 \mathrm{~T} 4$ & + \\
\hline $5 \mathrm{~T} 1$ & - & $5 \mathrm{~T} 2$ & - & $5 T 3$ & - & $5 \mathrm{~T} 4$ & - \\
\hline $6 \mathrm{~T} 1$ & + & $6 \mathrm{~T} 2$ & + & $6 \mathrm{T3}$ & + & $6 \mathrm{~T} 4$ & - \\
\hline 7T1 & + & $7 \mathrm{~T} 2$ & - & $7 T 3$ & - & $7 \mathrm{~T} 4$ & - \\
\hline $8 \mathrm{~T} 1$ & + & $8 \mathrm{~T} 2$ & + & $8 \mathrm{~T} 3$ & + & $8 \mathrm{~T} 4$ & - \\
\hline 9T1 & - & $9 \mathrm{~T} 2$ & + & $9 T 3$ & - & 9T4 & - \\
\hline 10T1 & + & $10 \mathrm{~T} 2$ & - & $10 \mathrm{T3}$ & - & $10 T 4$ & - \\
\hline $11 \mathrm{~T} 1$ & - & $11 \mathrm{~T} 2$ & - & $11 T 3$ & & $11 \mathrm{~T} 4$ & - \\
\hline $12 \mathrm{~T} 1$ & + & $12 \mathrm{~T} 2$ & - & $12 T 3$ & - & $12 \mathrm{~T} 4$ & + \\
\hline $13 \mathrm{~T} 1$ & - & $13 \mathrm{~T} 2$ & - & $13 T 3$ & + & $13 \mathrm{~T} 4$ & - \\
\hline $14 \mathrm{~T} 1$ & + & $14 \mathrm{~T} 2$ & + & $14 \mathrm{~T} 3$ & - & $14 \mathrm{~T} 4$ & + \\
\hline $15 \mathrm{~T} 1$ & - & $15 \mathrm{~T} 2$ & + & $15 T 3$ & + & $15 \mathrm{~T} 4$ & + \\
\hline $16 \mathrm{~T} 1$ & - & $16 \mathrm{~T} 2$ & - & $16 \mathrm{~T} 3$ & - & $16 \mathrm{~T} 4$ & - \\
\hline 17T1 & - & $17 \mathrm{~T} 2$ & + & $17 T 3$ & + & $17 T 4$ & - \\
\hline $18 \mathrm{~T} 1$ & - & $18 \mathrm{~T} 2$ & + & $18 \mathrm{~T} 3$ & - & $18 \mathrm{~T} 4$ & - \\
\hline 19T1 & - & 19T2 & - & 19T3 & - & $19 T 4$ & - \\
\hline $20 \mathrm{T1}$ & - & $20 \mathrm{~T} 2$ & - & $20 T 3$ & - & $20 T 4$ & - \\
\hline $21 \mathrm{~T} 1$ & - & $21 \mathrm{~T} 2$ & - & $21 \mathrm{~T} 3$ & - & $21 T 4$ & - \\
\hline $22 \mathrm{~T} 1$ & + & $22 \mathrm{~T} 2$ & - & $22 T 3$ & + & 22T4 & - \\
\hline 23T1 & - & $23 \mathrm{~T} 2$ & - & $23 T 3$ & + & $23 \mathrm{~T} 4$ & + \\
\hline $24 \mathrm{~T} 1$ & - & $24 \mathrm{~T} 2$ & - & $24 \mathrm{~T} 3$ & - & $24 \mathrm{~T} 4$ & - \\
\hline $25 \mathrm{~T} 1$ & - & $25 \mathrm{~T} 2$ & - & $25 T 3$ & - & $25 T 4$ & + \\
\hline $26 \mathrm{~T} 1$ & - & $26 \mathrm{~T} 2$ & - & $26 \mathrm{~T} 3$ & - & $26 \mathrm{~T} 4$ & - \\
\hline $27 \mathrm{~T} 1$ & + & $27 \mathrm{~T} 2$ & + & $27 T 3$ & - & $27 \mathrm{~T} 4$ & - \\
\hline $28 \mathrm{~T} 1$ & + & $28 \mathrm{~T} 2$ & + & $28 \mathrm{~T} 3$ & - & $28 \mathrm{~T} 4$ & - \\
\hline 29T1 & - & 29T2 & + & $29 T 3$ & - & 29T4 & - \\
\hline 30T1 & - & 30T2 & + & $30 T 3$ & - & $30 T 4$ & - \\
\hline $31 \mathrm{~T} 1$ & - & $31 \mathrm{~T} 2$ & + & $31 \mathrm{T3}$ & - & $31 \mathrm{T4}$ & - \\
\hline $32 \mathrm{~T} 1$ & - & $32 \mathrm{~T} 2$ & - & $32 T 3$ & - & $32 T 4$ & - \\
\hline 33T1 & - & $33 \mathrm{~T} 2$ & - & $33 \mathrm{T3}$ & - & $33 \mathrm{~T} 4$ & - \\
\hline $34 \mathrm{~T} 1$ & + & $34 \mathrm{~T} 2$ & + & $34 \mathrm{~T} 3$ & + & $34 \mathrm{~T} 4$ & - \\
\hline $35 \mathrm{~T} 1$ & - & $35 T 2$ & - & $35 T 3$ & - & $35 T 4$ & + \\
\hline $36 \mathrm{~T} 1$ & - & $36 \mathrm{~T} 2$ & - & $36 \mathrm{T3}$ & - & $36 \mathrm{~T} 4$ & - \\
\hline $37 \mathrm{~T} 1$ & - & $37 T 2$ & - & $37 T 3$ & - & $37 T 4$ & - \\
\hline $41 \mathrm{~T} 1$ & + & $38 \mathrm{~T} 2$ & + & $38 \mathrm{~T} 3$ & - & $38 \mathrm{~T} 4$ & - \\
\hline $46 \mathrm{~T} 1$ & + & 39T2 & + & 39T3 & - & 39T4 & - \\
\hline 47T1 & + & $40 \mathrm{~T} 2$ & + & $40 T 3$ & - & $40 T 4$ & - \\
\hline $51 \mathrm{~T} 1$ & + & $41 \mathrm{~T} 2$ & + & $41 T 3$ & & $41 \mathrm{T4}$ & - \\
\hline $52 \mathrm{~T} 1$ & + & $42 \mathrm{~T} 2$ & - & $42 T 3$ & - & $42 \mathrm{~T} 4$ & - \\
\hline $53 \mathrm{~T} 1$ & + & $43 \mathrm{~T} 2$ & - & $43 T 3$ & - & $43 \mathrm{~T} 4$ & - \\
\hline $102 \mathrm{~T} 1$ & + & $45 \mathrm{~T} 2$ & + & $44 \mathrm{~T} 3$ & - & $44 \mathrm{~T} 4$ & - \\
\hline 108T1 & + & $52 \mathrm{~T} 2$ & + & $45 T 3$ & - & $45 T 4$ & - \\
\hline 109T1 & + & $63 \mathrm{~T} 2$ & + & $46 \mathrm{T3}$ & - & $46 \mathrm{~T} 4$ & - \\
\hline $113 \mathrm{~T} 1$ & + & $72 \mathrm{~T} 2$ & + & $47 T 3$ & - & 47T4 & - \\
\hline $114 \mathrm{~T} 1$ & + & 79T2 & + & $48 \mathrm{~T} 3$ & - & $48 \mathrm{~T} 4$ & - \\
\hline $115 \mathrm{~T} 1$ & + & $80 T 2$ & + & $49 T 3$ & - & 49T4 & - \\
\hline $117 \mathrm{~T} 1$ & + & $85 \mathrm{~T} 2$ & + & $62 T 3$ & + & $50 T 4$ & - \\
\hline
\end{tabular}


Table S2. Absolute frequency ( $\mathrm{N}$ ) and relative frequency (\%) of positive and negative results of the root colonization test of 200 bacterial strains obtained from non-rhizospheric soil enriched with different doses of biochar collected at the Experimental Station of Tropical Fruticulture - EEFT/INPA, in Manaus, Amazonas state (Brazil).

\begin{tabular}{cccccc}
\hline \multirow{2}{*}{$\begin{array}{c}\text { Biochar } \\
\text { dose } \\
\left.\text { (t ha- }^{-1}\right)\end{array}$} & \multicolumn{4}{c}{ Growth promotion } & \multirow{2}{*}{ Total } \\
\cline { 2 - 4 } & \multicolumn{2}{c}{ Positive } & \multicolumn{2}{c}{ Negative } & \\
\hline 0 & $\mathbf{N}$ & $\%$ & $\mathbf{N}$ & $\%$ & \\
40 & 25 & 50 & 25 & 50 & $50(25 \%)$ \\
80 & 9 & 56 & 22 & 44 & $50(25 \%)$ \\
120 & 8 & 18 & 41 & 82 & $50(25 \%)$ \\
\hline Total & 70 & 35 & 42 & 84 & $50(25 \%)$ \\
\hline
\end{tabular}

Table S3. Average plant height (PH), stem diameter (SD), number of leaves (NL) and dry mass of the aerial part (DMAP) of tomato seedlings 20 days after sowing on Vivatto Plus ${ }^{\circledast}$ substrate and inoculated with each of 53 bacterial strains from Amazon biochar-enriched soil. Values are the mean \pm SD of five replicates. Ctrl$=$ negative control. Different upper-case letters in the same columns indicate statistically significant differences at $\mathrm{p}<0.05 .{ }^{1} \mathrm{~S}$ cott-Knott test; ${ }^{2} \mathrm{Dunn}$ test. CV\% $=$ coefficient of variance.

\begin{tabular}{|c|c|c|c|c|}
\hline Strain & $\mathrm{PH}^{1}(\mathrm{~cm})$ & $\mathrm{NL}^{2}$ & $\operatorname{DMAP}(\mathrm{g})^{1}$ & $\mathrm{SD}(\mathrm{mm})^{1}$ \\
\hline Ctrl-* & $11.6 \pm 0.4^{b}$ & $2.0 \pm 0.7^{d}$ & $0.0 \pm 0.0^{b}$ & $2.0 \pm 0.2^{b}$ \\
\hline $6 \mathrm{~T} 3$ & $14.9 \pm 0.3^{\mathrm{a}}$ & $3.0 \pm 0.6^{\mathrm{abcd}}$ & $0.1 \pm 0.0^{\mathrm{a}}$ & $2.5 \pm 0.2^{\mathrm{a}}$ \\
\hline $6 \mathrm{~T} 2$ & $10.4 \pm 0.6^{c}$ & $2.7 \pm 0.6^{c d}$ & $0.0 \pm 0.0^{b}$ & $1.9 \pm 0.3^{b}$ \\
\hline $62 T 3$ & $11.8 \pm 0.3^{b}$ & $2.7 \pm 0.6^{\mathrm{bcd}}$ & $0.1 \pm 0.0^{b}$ & $2.1 \pm 0.3^{b}$ \\
\hline $72 T 2$ & $11.5 \pm 0.4^{b}$ & $2.3 \pm 0.7^{c d}$ & $0.1 \pm 0.0^{b}$ & $2.0 \pm 0.3^{b}$ \\
\hline $34 \mathrm{~T} 1$ & $11.4 \pm 0.7^{b}$ & $3.3 \pm 0.4^{\mathrm{abc}}$ & $0.1 \pm 0.0^{b}$ & $1.9 \pm 0.2^{b}$ \\
\hline 109T1 & $10.8 \pm 0.3^{b}$ & $2.3 \pm 0.4^{c d}$ & $0.0 \pm 0.0^{b}$ & $1.9 \pm 0.2^{b}$ \\
\hline 117T1 & $13.1 \pm 0.3^{\mathrm{a}}$ & $2.7 \pm 0.5^{c d}$ & $0.1 \pm 0.0^{\mathrm{a}}$ & $2.0 \pm 0.2^{b}$ \\
\hline $3 \mathrm{~T} 4$ & $13.8 \pm 0.2^{\mathrm{a}}$ & $3.7 \pm 0.5^{\mathrm{abc}}$ & $0.1 \pm 0.0^{b}$ & $2.1 \pm 0.2^{b}$ \\
\hline $28 \mathrm{~T} 1$ & $11.7 \pm 0.2^{b}$ & $3.3 \pm 0.4^{\mathrm{abcd}}$ & $0.1 \pm 0.0^{b}$ & $2.1 \pm 0.2^{b}$ \\
\hline $30 T 2$ & $14.5 \pm 0.5^{a}$ & $4.7 \pm 0.5^{a}$ & $0.1 \pm 0.0^{\mathrm{a}}$ & $2.5 \pm 0.2^{a}$ \\
\hline $47 \mathrm{~T} 1$ & $14.0 \pm 0.5^{a}$ & $3.0 \pm 0.4^{\mathrm{abcd}}$ & $0.1 \pm 0.0^{\mathrm{a}}$ & $2.4 \pm 0.3^{\mathrm{a}}$ \\
\hline $80 T 2$ & $14.0 \pm 0.5^{a}$ & $3.7 \pm 0.4^{\mathrm{abc}}$ & $0.1 \pm 0.0^{\mathrm{a}}$ & $2.5 \pm 0.3^{\mathrm{a}}$ \\
\hline $10 \mathrm{~T} 1$ & $11.8 \pm 0.4^{b}$ & $2.7 \pm 0.5^{\mathrm{bcd}}$ & $0.1 \pm 0.0^{b}$ & $1.9 \pm 0.3^{b}$ \\
\hline $28 \mathrm{~T} 2$ & $14.1 \pm 0.3^{\mathrm{a}}$ & $3.0 \pm 0.4^{\mathrm{abcd}}$ & $0.1 \pm 0.0^{\mathrm{a}}$ & $2.4 \pm 0.3^{a}$ \\
\hline $46 \mathrm{~T} 1$ & $14.3 \pm 0.6^{a}$ & $3.3 \pm 0.4^{\mathrm{abc}}$ & $0.1 \pm 0.0^{\mathrm{a}}$ & $2.3 \pm 0.2^{a}$ \\
\hline $1 \mathrm{~T} 2$ & $10.3 \pm 0.2^{c}$ & $2.0 \pm 0.5^{d}$ & $0.0 \pm 0.0^{b}$ & $1.6 \pm 0.3^{b}$ \\
\hline $4 \mathrm{~T} 2$ & $13.1 \pm 0.3^{a}$ & $2.0 \pm 0.6^{d}$ & $0.1 \pm 0.0^{\mathrm{a}}$ & $2.2 \pm 0.3^{b}$ \\
\hline $4 \mathrm{~T} 4$ & $10.2 \pm 0.3^{c}$ & $2.0 \pm 0.5^{d}$ & $0.1 \pm 0.0^{b}$ & $1.7 \pm 0.2^{b}$ \\
\hline $8 \mathrm{~T} 1$ & $10.1 \pm 0.3^{c}$ & $3.0 \pm 0.4^{\mathrm{abcd}}$ & $0.0 \pm 0.0^{b}$ & $1.9 \pm 0.2^{b}$ \\
\hline $85 T 2$ & $11.6 \pm 0.2^{b}$ & $3.0 \pm 0.5^{\text {abcd }}$ & $0.1 \pm 0.0^{b}$ & $2.1 \pm 0.2^{b}$ \\
\hline $2 \mathrm{~T} 2$ & $13.6 \pm 0.4^{a}$ & $3.0 \pm 0.4^{\mathrm{abcd}}$ & $0.1 \pm 0.0^{\mathrm{a}}$ & $2.6 \pm 0.2^{a}$ \\
\hline $41 T 1$ & $11.6 \pm 0.5^{b}$ & $2.3 \pm 0.4^{c d}$ & $0.1 \pm 0.0^{b}$ & $1.9 \pm 0.3^{b}$ \\
\hline $79 T 2$ & $11.4 \pm 0.2^{b}$ & $2.3 \pm 0.7^{\mathrm{cd}}$ & $0.1 \pm 0.0^{b}$ & $1.9 \pm 0.3^{b}$ \\
\hline $8 \mathrm{~T} 2$ & $13.6 \pm 0.3^{\mathrm{a}}$ & $3.7 \pm 0.4^{\mathrm{abc}}$ & $0.1 \pm 0.0^{\mathrm{a}}$ & $2.2 \pm 0.2^{a}$ \\
\hline $115 \mathrm{~T} 1$ & $14.6 \pm 0.3^{\mathrm{a}}$ & $3.7 \pm 0.5^{\mathrm{abc}}$ & $0.1 \pm 0.0^{\mathrm{a}}$ & $2.3 \pm 0.2^{a}$ \\
\hline $12 T 4$ & $14.7 \pm 0.4^{\mathrm{a}}$ & $3.3 \pm 0.4^{\mathrm{abc}}$ & $0.1 \pm 0.0^{\mathrm{a}}$ & $2.6 \pm 0.2^{a}$ \\
\hline $8 \mathrm{~T} 3$ & $12.1 \pm 0.4^{b}$ & $3.0 \pm 0.5^{\mathrm{abcd}}$ & $0.1 \pm 0.0^{b}$ & $1.9 \pm 0.2^{b}$ \\
\hline $12 \mathrm{~T} 1$ & $11.3 \pm 0.4^{b}$ & $2.3 \pm 0.7^{\mathrm{cd}}$ & $0.0 \pm 0.0^{b}$ & $1.9 \pm 0.2^{b}$ \\
\hline $6 \mathrm{~T} 1$ & $12.9 \pm 0.4^{\mathrm{a}}$ & $3.0 \pm 0.4^{\mathrm{abcd}}$ & $0.1 \pm 0.0^{\mathrm{a}}$ & $2.1 \pm 0.2^{b}$ \\
\hline $15 T 4$ & $10.3 \pm 0.5^{c}$ & $2.0 \pm 0.6^{d}$ & $0.0 \pm 0.0^{b}$ & $1.7 \pm 0.3^{b}$ \\
\hline $15 T 2$ & $13.0 \pm 0.3^{a}$ & $3.0 \pm 0.4^{\mathrm{abcd}}$ & $0.1 \pm 0.0^{\mathrm{a}}$ & $1.6 \pm 0.2^{b}$ \\
\hline $15 T 3$ & $7.7 \pm 0.4^{d}$ & $2.3 \pm 0.6^{c d}$ & $0.0 \pm 0.0^{b}$ & $1.1 \pm 0.3^{b}$ \\
\hline $13 T 3$ & $11.5 \pm 0.2^{b}$ & $2.0 \pm 0.5^{d}$ & $0.1 \pm 0.0^{b}$ & $2.0 \pm 0.2^{b}$ \\
\hline 7T1 & $12.9 \pm 0.4^{\mathrm{a}}$ & $3.3 \pm 0.5^{\mathrm{abc}}$ & $0.1 \pm 0.0^{\mathrm{a}}$ & $2.4 \pm 0.3^{a}$ \\
\hline
\end{tabular}

Table S3. Continued.

\begin{tabular}{|c|c|c|c|c|}
\hline Strain & $\mathrm{PH}^{1}(\mathrm{~cm})$ & $\mathrm{NL}^{2}$ & $\operatorname{DMAP}(\mathrm{g})^{1}$ & $\mathrm{SD}(\mathrm{mm})^{1}$ \\
\hline $52 \mathrm{~T} 2$ & $13.2 \pm 0.3^{a}$ & $2.7 \pm 0.7^{b c d}$ & $0.1 \pm 0.0^{\mathrm{a}}$ & $2.5 \pm 0.2^{\mathrm{a}}$ \\
\hline $35 T 4$ & $13.0 \pm 0.4^{a}$ & $2.0 \pm 0.5^{d}$ & $0.1 \pm 0.0^{b}$ & $1.7 \pm 0.2^{b}$ \\
\hline $25 T 4$ & $13.2 \pm 0.3^{a}$ & $2.3 \pm 0.7^{\mathrm{cd}}$ & $0.1 \pm 0.0^{\mathrm{a}}$ & $1.9 \pm 0.3^{b}$ \\
\hline $22 T 3$ & $15.7 \pm 0.2^{\mathrm{a}}$ & $3.7 \pm 0.5^{\mathrm{abc}}$ & $0.1 \pm 0.0^{\mathrm{a}}$ & $2.7 \pm 0.2^{\mathrm{a}}$ \\
\hline $53 \mathrm{T1}$ & $15.1 \pm 0.4^{a}$ & $2.0 \pm 0.7^{d}$ & $0.1 \pm 0.0^{\mathrm{a}}$ & $2.1 \pm 0.2^{b}$ \\
\hline $23 T 3$ & $13.9 \pm 0.3^{\mathrm{a}}$ & $2.3 \pm 0.4^{c d}$ & $0.1 \pm 0.0^{\mathrm{a}}$ & $2.4 \pm 0.2 \mathrm{a}$ \\
\hline $52 \mathrm{~T} 1$ & $13.6 \pm 0.3^{a}$ & $4.3 \pm 0.5^{\mathrm{ab}}$ & $0.1 \pm 0.0^{\mathrm{a}}$ & $2.4 \pm 0.3 a$ \\
\hline $22 \mathrm{~T} 1$ & $8.6 \pm 0.4^{d}$ & $2.3 \pm 0.5^{\mathrm{cd}}$ & $0.0 \pm 0.0^{b}$ & $1.5 \pm 0.3^{b}$ \\
\hline $102 T 1$ & $11.5 \pm 0.6^{b}$ & $2.7 \pm 0.4^{c^{c d}}$ & $0.1 \pm 0.0^{b}$ & $2.1 \pm 0.3 b$ \\
\hline $14 \mathrm{~T} 1$ & $10.9 \pm 0.3^{b}$ & $2.0 \pm 0.5^{d}$ & $0.1 \pm 0.0^{b}$ & $1.7 \pm 0.2 b$ \\
\hline $27 \mathrm{~T} 1$ & $11.8 \pm 0.5^{b}$ & $2.0 \pm 0.4^{d}$ & $0.1 \pm 0.0^{b}$ & $2.1 \pm 0.3 b$ \\
\hline 108T1 & $11.0 \pm 0.3^{b}$ & $3.0 \pm 0.5^{\mathrm{abcd}}$ & $0.1 \pm 0.0^{b}$ & $2.4 \pm 0.3 a$ \\
\hline $114 \mathrm{~T} 1$ & $13.9 \pm 0.4^{\mathrm{a}}$ & $3.0 \pm 0.6^{\mathrm{abcd}}$ & $0.1 \pm 0.0^{\mathrm{a}}$ & $2.4 \pm 0.2 \mathrm{a}$ \\
\hline $17 T 3$ & $14.5 \pm 0.3^{\mathrm{a}}$ & $2.3 \pm 0.4^{\text {cd }}$ & $0.1 \pm 0.0^{\mathrm{a}}$ & $2.7 \pm 0.2 a$ \\
\hline $17 T 2$ & $11.0 \pm 0.3^{b}$ & $2.0 \pm 0.6^{d}$ & $0.1 \pm 0.0^{b}$ & $1.9 \pm 0.2 b$ \\
\hline $51 T 1$ & $11.4 \pm 0.3^{b}$ & $3.3 \pm 0.5^{a b c}$ & $0.1 \pm 0.0^{b}$ & $2.0 \pm 0.3 b$ \\
\hline $39 T 2$ & $10.1 \pm 0.4^{c}$ & $2.3 \pm 0.7^{c d}$ & $0.0 \pm 0.0^{b}$ & $1.9 \pm 0.2 b$ \\
\hline $63 T 2$ & $11.5 \pm 0.4^{b}$ & $2.7 \pm 0.7^{c d}$ & $0.1 \pm 0.0^{b}$ & $2.1 \pm 0.2 b$ \\
\hline $113 \mathrm{~T} 1$ & $12.6 \pm 0.4^{a}$ & $3.0 \pm 0.5^{\mathrm{abcd}}$ & $0.1 \pm 0.0^{\mathrm{a}}$ & $2.4 \pm 0.2 \mathrm{a}$ \\
\hline CV\% & 8.90 & - & 14.54 & 16.17 \\
\hline
\end{tabular}

Table S4. Absolute frequency $(\mathrm{N})$ and relative frequency (\%) of positive and negative results of the growth promotion test of 25 bacterial strains obtained from non-rhizospheric soil enriched with different doses of biochar collected at the Experimental Station of Tropical Fruticulture - EEFT/INPA, in Manaus, Amazonas state (Brazil).

\begin{tabular}{cccccc}
\hline \multirow{2}{*}{$\begin{array}{c}\text { Biochar } \\
\text { dose } \\
\left.\text { (t ha- }^{-1}\right)\end{array}$} & \multicolumn{4}{c}{ Growth promotion } & \\
\cline { 2 - 5 } & \multicolumn{2}{c}{ Positive } & \multicolumn{2}{c}{ Negative } & \multirow{2}{*}{ Total } \\
\hline 0 & 4 & $\%$ & $\mathbf{N}$ & $\%$ & \\
\hline 40 & 4 & 50.0 & 6 & 60.0 & $10(40 \%)$ \\
80 & 3 & 62.5 & 1 & 37.5 & $8(32 \%)$ \\
120 & 2 & 66.7 & 1 & 33.3 & $3(12 \%)$ \\
\hline Total & 13 & 52.0 & 12 & 48.0 & $25(100 \%)$ \\
\hline
\end{tabular}

Table S5. Absolute frequency ( $\mathrm{N}$ ) and relative frequency (\%) of positive and negative results of the phosphate solubilization test of 25 bacterial strains obtained from non-rhizospheric soil enriched with different doses of biochar collected at the Experimental Station of Tropical Fruticulture - EEFT/INPA, in Manaus, Amazonas state (Brazil).

\begin{tabular}{cccccc}
\hline \multirow{2}{*}{$\begin{array}{c}\text { Biochar } \\
\text { dose }\end{array}$} & \multicolumn{3}{c}{ Phosphate solubilization } & \multirow{2}{*}{ Total } \\
\cline { 2 - 4 }$\left(\right.$ t ha $\left.^{-1}\right)$ & $\mathbf{c}$ Positive & \multicolumn{2}{c}{ Negative } & \\
\cline { 2 - 4 } & $\mathbf{N}$ & $\%$ & $\mathbf{N}$ & $\%$ & \\
\hline 0 & 0 & 0 & 10 & 100 & $10(40 \%)$ \\
40 & 0 & 0 & 8 & 100 & $8(32 \%)$ \\
80 & 0 & 0 & 4 & 100 & $4(16 \%)$ \\
120 & 2 & 66.7 & 1 & 33.3 & $3(12 \%)$ \\
\hline Total & 2 & 8.0 & 23 & 92.0 & $25(100 \%)$ \\
\hline
\end{tabular}


Table S6. Identity between the bacterial-strain sequences obtained from a central Amazon soil sample enriched with biochar and sequences deposited in GenBank.

\begin{tabular}{|c|c|c|c|c|c|}
\hline Strain & GenBank code & Size (bp) & ID Blast \% & SDT ID score\%* & GenBank code/Related species \\
\hline $8 \mathrm{~T} 2$ & MH547253 & 1354 & 99 & 99.9 & KX245015/Bacillus thuringiensis \\
\hline $17 T 3$ & MH547254 & 1256 & 99 & 91.9 & MG205930/Bacillus thuringiensis \\
\hline $23 T 3$ & MH547255 & 1293 & 99 & 95.9 & MG205930/Bacillus thuringiensis \\
\hline $115 \mathrm{~T} 1$ & MH547256 & 1265 & 99 & 92.9 & KF527213/Lysinibacillus sphaericus \\
\hline $28 \mathrm{~T} 2$ & MH547257 & 1354 & 98 & 98.5 & KX057625/Bacillus cereus \\
\hline $53 \mathrm{~T} 1$ & MH547258 & 1354 & 98 & 98.6 & KX950679/ Bacillus cereus \\
\hline $80 \mathrm{~T} 2$ & MH547259 & 908 & 95 & 64.0 & KX057625/ Bacillus cereus \\
\hline $117 \mathrm{~T} 1$ & MH547261 & 1354 & 94 & 94.3 & KX057625/ Bacillus cereus \\
\hline $3 \mathrm{~T} 4$ & MH547260 & 1355 & 99 & 99.3 & KX245015 / Bacillus thuringiensis \\
\hline $6 \mathrm{~T} 3$ & MH547262 & 1356 & 99 & 99.4 & MF370350/ Bacillus cereus \\
\hline $113 T 1$ & MH547263 & 1311 & 98 & 96.9 & KX057625/ Bacillus cereus \\
\hline $2 \mathrm{~T} 2$ & MH547265 & 1354 & 99 & 98.8 & KF033125/ Bacillus cereus \\
\hline $30 T 2$ & MH547266 & 1353 & 99 & 99.1 & MF370350/ Bacillus cereus \\
\hline $12 T 4$ & MH547264 & 815 & 98 & 58.3 & KR999903/ Bacillus flexus \\
\hline $4 \mathrm{~T} 2$ & MH547267 & 1358 & 99 & 91.7 & MG984077/Lysinibacillus macroides \\
\hline $6 \mathrm{~T} 1$ & MH547268 & 815 & 94 & 91.4 & KY780512/Bacillus cereus \\
\hline $7 \mathrm{TT}$ & MH547270 & 1354 & 88 & 87.7 & JF701942/Bacillus sp. \\
\hline $46 \mathrm{~T} 1$ & MH547269 & 1315 & 96 & 97.4 & KU922484/Bacillus altitudinis \\
\hline $25 T 4$ & MH547271 & 1355 & 96 & 96.1 & KX268131/Bacillus megaterium \\
\hline $47 \mathrm{~T} 1$ & MH547272 & 1363 & 95 & 95.3 & KX057625/Bacillus cereus \\
\hline $114 \mathrm{~T} 1$ & MH547273 & 768 & 99 & 99.5 & EU982902/Lysinibacillus sphaericus \\
\hline $22 \mathrm{T3}$ & MH547274 & 1358 & 98 & 98.8 & KX816414/Bacillus cereus \\
\hline $52 T 1$ & MH547275 & 1307 & 95 & 96.7 & KF033125/Bacillus cereus \\
\hline
\end{tabular}

* Based on the Sequence Demarcation Tool (SDT v.1.2)

Table S7. Absolute frequency $(\mathrm{N})$ and relative frequency (\%) of positive and negative results of the indole acetic acid production test of 25 bacterial strains obtained from non-rhizospheric soil enriched with different doses of biochar collected at the Experimental Station of Tropical Fruticulture - EEFT/INPA, in Manaus, Amazonas state (Brazil).

\begin{tabular}{cccccc}
\hline \multirow{2}{*}{$\begin{array}{c}\text { Biochar } \begin{array}{c}\text { dose } \\
\text { d ha }\end{array} \\
\text {-1 })\end{array}$} & \multicolumn{4}{c}{ Positive } & \multicolumn{2}{c}{ Negative } & \multirow{2}{*}{ Total } \\
\cline { 2 - 4 } & $\mathbf{N}$ & $\%$ & $\mathbf{N}$ & $\%$ & \\
\hline 0 & 7 & 70.0 & 3 & 30.0 & $10(40 \%)$ \\
40 & 6 & 75.0 & 2 & 25.0 & $8(32 \%)$ \\
80 & 2 & 50.0 & 2 & 50.0 & $4(16 \%)$ \\
120 & 2 & 66.7 & 1 & 33.3 & $3(12 \%)$ \\
\hline Total & 17 & 68.0 & 8 & 32.0 & $25(100 \%)$ \\
\hline
\end{tabular}

Table S8. Absolute frequency $(\mathrm{N})$ and relative frequency (\%) of positive and negative results of the resistance induction test of 25 bacterial strains obtained from non-rhizospheric soil enriched with different doses of biochar collected at the Experimental Station of Tropical Fruticulture - EEFT/INPA, in Manaus, Amazonas state (Brazil).

\begin{tabular}{cccccc}
\hline \multirow{2}{*}{$\begin{array}{c}\text { Biochar } \\
\text { dose } \\
\text { (t ha-1) }\end{array}$} & \multicolumn{4}{c}{ Resistance induction } & \multirow{2}{*}{ Total } \\
\cline { 2 - 4 } & \multicolumn{2}{c}{ Positive } & \multicolumn{2}{c}{ Negative } & \\
\hline 0 & $\mathbf{N}$ & $\%$ & $\mathbf{N}$ & $\%$ & \\
\hline 40 & 3 & 37.5 & 5 & 62.5 & $8(32 \%)$ \\
80 & 2 & 50.0 & 2 & 50.0 & $4(16 \%)$ \\
120 & 2 & 0 & 1 & 100 & $3(12 \%)$ \\
\hline Total & 14 & 56.0 & 11 & 44.0 & $25(100 \%)$ \\
\hline
\end{tabular}

